\title{
Workplace Situation and Well-Being of Ecuadorian Self-Employed
}

\author{
Nuria Ceular-Villamandos ${ }^{1}$, Virginia Navajas-Romero ${ }^{1, *}$ [C, Lorena Caridad y López del Río ${ }^{1}$ (I) \\ and Lucia Zita Zambrano-Santos ${ }^{2}$
}

1 Department of Statistics and Operations Research, Business Organization and Applied Economics, Universidad de Córdoba, 14071 Córdoba, Spain; td1cevin@uco.es (N.C.-V.); d92calol@uco.es (L.C.yL.d.R.)

2 Strategic Planning Department, Universidad San Gregorio de Portoviejo, Portoviejo 2005, Ecuador; zlzambrano@sangregorio.edu.es

* Correspondence: vnavajas@uco.es

Citation: Ceular-Villamandos, N.; Navajas-Romero, V.; Caridad y López del Río, L.; Zambrano-Santos, L.Z. Workplace Situation and Well-Being of Ecuadorian Self-Employed.

Sustainability 2021, 13, 1892.

https://doi.org/10.3390/su13041892

Academic Editor: Gabriele Giorgi

Received: 1 December 2020

Accepted: 2 February 2021

Published: 9 February 2021

Publisher's Note: MDPI stays neutral with regard to jurisdictional claims in published maps and institutional affiliations.

Copyright: (c) 2021 by the authors. Licensee MDPI, Basel, Switzerland. This article is an open access article distributed under the terms and conditions of the Creative Commons Attribution (CC BY) license (https:/ / creativecommons.org/licenses/by/ $4.0 /)$.

\begin{abstract}
Due to novel coronavirus 2019 (COVID-19), the labor market is going to undergo a profound restructuring. The creation of a new labor paradigm by all stakeholders is essential. This document contributes to the current political and social debates about self-employment, the need for economic growth, and how these labor measures, which are deeply institutionalized, need a change of attitude for an adequate job reconstruction in terms of welfare and sustainability. Currently, policy makers are proposing actions and policies because the new labor paradigm is being designed in the countries of Latin America. This research aims to analyze the JDCS model (Job Demand-Control-Support) and well-being in the self-employed in Ecuador. Unlike previous studies, this research takes a comprehensive approach by considering this theoretical model and the figure of the self-employed in terms of well-being. The logistic model, using cases of more than one thousand workers, generated estimated results that indicate the existence of a significant effect of physical and psychological demands at work on the balance between well-being and the management of angry clients; the speed of execution; and the complexity of the tasks. Regarding labor control, the ability to solve problems and make decisions for the company are detected as influencing factors; finally, social support is another factor influencing global well-being for the self-employed. These results show that with an effective management of the self-employed labor environment, it is possible to achieve an adequate level of workplace satisfaction.
\end{abstract}

Keywords: self-employed; well-being; job demand; job control; social support; entrepreneurship; autonomy; Ecuador

\section{Introduction}

The novel coronavirus 2019 (COVID-19) pandemic has been unpredictable, and its results have not yet been quantified [1,2]. Restrictions on mass gatherings and social distancing requirements have limited entrepreneurship, leading to decreased profits and an increase in the number of businesses that have closed [3]. At the global level, the workforce and specifically the self-employed have been deeply affected by the pandemic. This circumstance supports their precariousness and vulnerability to external shocks due to the fact that the self-employed, before the pandemic, was defined by a clear deterioration in the working conditions of micro-entrepreneurs determined by factors such as subsistence and the need for employment, financial, and economic resources [4]. This has led to a change in the work environment with profound consequences such as increased unemployment and online working [5].

It is critical to identify and acknowledge the difficult conditions that self-employed workers face as a result of the global pandemic. Our approach is based on pointing out which are the labor factors that increase the well-being of the self-employed, so that the actions and measures that governments and companies take on these members of 
the workforce are adequate and provide a new labor context based on in sustainability. The consequences that the COVID-19 pandemic has caused in the self-employed should not cause an expansion and amplification of the already known challenges experienced by this work group, based on precariousness, low levels of remuneration and poor working conditions. The pandemic raises the possibility of rebuilding this figure in terms of wellbeing and sustainability $[3,6]$. Given this situation, the proposal of solid policies aimed at stimulating economic growth and entrepreneurship, as key agents [7] in future sustainable labor integration processes, should be a priority concern for policy makers [8], based on the protection of the health, safety and well-being of the actors that make up the work environment [9].

Well-being and poverty alleviation are outstanding issues after the adoption of the United Nations World Development Goals (WDGs) in 2000. The Sustainable Development Goals (SDGs) of 2015 are established within this framework-specifically, goals 3 and 8, which combine dimensions such as well-being and decent working conditions. Ecuador is aligned with the SDGs through the National Development Plan, "All a Life", incorporating in its policies actions such as the guarantee of access to decent work and social security, seeking to generate skills and promote job opportunities in conditions of equality [10]. Labor well-being becomes one of the proposals focused on the labor market as a tool to stimulate sustainable economic growth [11] and to be able to face the actual economic challenges through concrete and dynamic actions of social responsibility in the field of well-being and employment [12]. Today, self-employed workers are at the center of many political issues related to aspects such as sustainability, poverty, human capital, endogenous resources, and employment, which are linked to regional and comparative advantages [13,14]. It is a key dimension in the organization of any modern society in the process of generating innovative social and commercial projects that contribute to social well-being $[15,16]$, and a potential force for the development, growth, and personal well-being $[17,18]$. Following this idea, companies become dynamic agents of the economy, offering new job opportunities, creating wealth, within modernization and adoption of technological changes [19]. In Latin America, the labor business context is more complex, due to the region's peculiarities in the economic, commercial, technological, and poverty fields [20]. Following this idea, some reports highlight the consequences that self-employed workers have suffered due to the pandemic, including the loss of their jobs and even their homes [21-23]. Evans and Over [23] highlight the difficult situation of the most vulnerable groups in society and more specifically focuses on the poorest countries in the South. According to the Economic Commission for Latin America and the Caribbean (ECLAC), the economic performance recorded in 2019 was poor, with GDP growth of only $0.1 \%$. Although it is extremely difficult to estimate the impact of the coronavirus on growth, a recession of $2.5 \%$ to $5.2 \%$ is set in 2020 [24]. Furthermore, in Latin America, approximately 130 million workers - that is, around 53\% of the employed population-work informally, and this circumstance represents an even greater challenge [25].

Ecuador is a developing country, with high levels of inequality and structural problems at the institutional and productive level $[26,27]$. Entrepreneurship in this geographical area is centralized in activities related to trade, which are those that have been most damaged by the pandemic and also stood out for presenting low competitiveness, little use of technology, limited innovation, and a majority of self-employed that operate forced by this environment conditions [28]. Ecuador has presented measures of partial and total confinement in the face of the COVID-19 pandemic. This fact has caused the economic activities of the country to have stopped, with the consequent consequences in terms of production, consumption, and employment. In this scenario, the Central Bank of Ecuador estimates a drop in GDP in 2020 of around $7 \%$ to $10 \%$, and ECLAC estimates that poverty will increase by about $5 \%$, and inequality will increase by more than $3 \%$ [24].

The Job Demand-Control-Support (JDCS) model [29-31] constitutes a quite useful theoretical approach to understand the characteristics of the workplace and its consequences on health [32]. In fact, this model has been used in many job market sectors with the aim of 
studying a wide range of reactions that cause tension in workers [33-38]. In subsequent model improvements, perceived support at work was included as another relevant factor. However, despite the great utility of these models, more empirical evidence is required in certain professional categories, such as the self-employed. Following this idea, the JDCS model establishes that factors such as demands and labor control will affect the development of well-being $[30,31,39]$. Following this idea, entrepreneurs are characterized by a combination of high demand and labor control [40].

Previous studies indicate the existence of a positive association between well-being and income [41,42]. Other authors show that well-being depends also on other factors such as health, social status, and family and work circumstances [43-47]. Therefore, the literature recognizes that business well-being is due to a large number of factors, beyond the economic factor [48], such as psychological environment [49], job satisfaction [50-52], and a sensation of independence [47]. Previous literature analyzes the well-being of the self-employed in specific geographic areas such as North America and Europe $[53,54]$ but not considering regions such as small developing countries. According to the literature, Ecuador has few studies that analyze the figure of the self-employed worker. For example, the autonomous work of family mothers and the work and family balance have been treated by some authors [55]; informal self-employed workers as a last resort for low-skilled workers indicates that a reduction in poverty could only be sustainable if more and better job opportunities are created [56]. Others study particular aspects such as the financial cost to access formal jobs [57], the minimum wage rate and how it influences the formal and informal rate [58], and the relationship between entrepreneurship and well-being [59-62]. This debate is of great importance in current academic research because it manages to connect well-being and decent work. This relationship is especially important in the current context due to the effects of the pandemic and the need to rebuild the business fabric.

The work model of self-employed workers and its relationship with long-term sustainability are determined, among other aspects, by public policies, labor regulations, and organizational practices. Therefore, the sustainability of the business labor market is determined by the working conditions of the self-employed, which, in turn, delimits well-being $[15,63]$. The underlying premise of this study is that there are differentiating characteristics for self-employed Ecuadorians that influence their level of well-being. Previous studies of job quality are carried out from the perspective of employed persons [40,64], forgetting the importance of the self-employed in the sustainable development of a developing country.

Specifically, the Republic of Ecuador is among the unequal countries in terms of development in Latin America and the Caribbean [65-67], and to our knowledge, there are no studies using the JDC model on the well-being of self-employed workers in the country, although they have been widely debated in other contexts [68]. In the absence of evidence on this reality [69], it is essential to generate knowledge about this phenomenon due, on the one hand, to the need for reconstruction in sustainable terms and, on the other, to the need to take care of this group that is so vulnerable in terms of precariousness. Policy makers must prioritize decision-making and evidence-based public interventions in order to improve the sustainability of working conditions in terms of well-being [70]. It is essential to create a new labor paradigm by all stakeholders, particularly consumers, governments, and industry itself, that will emerge from the pandemic based on the creation of new attitudes toward work and workers. This raises questions about self-employed workers and how stakeholders are going to approach the reconstruction of the labor market, since there are deeply established aspects of the labor market that were systemic in terms of precariousness. This circumstance must be considered by policy makers, institutions, and markets.

In this context, the measurement and conceptualization of the well-being of the self-employed worker has not received enough attention despite significant research, over decades on well-being in life and work [15]. There is a gap in the literature regarding the exploration of the relationship between well-being at work and the self-employed 
within a uniform and coherent framework [71], as well as in the mechanisms that lead to well-being [15]. This study attempts to contribute to fulfill this gap by exploring labor well-being in Ecuador from an organizational perspective and considering the perceptions of self-employed workers, which could allow the identification of possible characteristics, based on pre-established regulations and patterns, related to interaction of the selfemployed and their work environment. This document contributes to current political and social debates about self-employment, the need for economic growth, and how these deeply institutionalized labor measures need a change in attitude to rebuild a labor model. This article aims to establish the basis for a deep reflection on the COVID-19 crisis, and what factors should be taken into account for the reconstruction of the autonomous labor market, providing a broader point of reference in terms of well-being and sustainability.

This can help understand what characteristics of the decent work model lead to higher levels of well-being within the context of the Ecuadorian self-employed in this period of reconstruction due to the pandemic. From these objectives, the following research question is derived: Do the working conditions of the Ecuadorian self-employed project a work model that reflects well-being in terms of sustainability?

\section{Theoretical Framework}

\subsection{JCDS Model}

The focus of the study is based on the well-being conditions of the self-employed in Ecuador, taking as a theoretical reference base the Job Demand-Control-Support (JDCS) model exposed by $[29,30,72]$. The JDCS model is a particularly influential theoretical approach in the field of occupational health and hence well-being. According to the concept, the relationship between job demands and poor health depends on the moderating effects of work control and social support. The applicability of the model is evident in numerous studies related to labor demands and their impact on the well-being of workers (for example, [73]).

Under these conditions, the JDC/JDCS models represent how the joint effects of work stressors (work demands or stress) and control at work (freedom of decision or control measures at work) affect the well-being of the self-employed, with the fact of an additional causal factor associated to social support. Therefore, work demands present stressful dimensions (physical and psychological stress), which normally occur in the day-to-day work of the self-employed; the control exercised by the autonomy over the activities it executes, in this case, the control over the execution, is related to the discretionary action and freedom of decision, it is who has the autonomy to carry out and control the initiatives and responsibilities assumed. These and social support, which represents the recognition that it reduces stress in the work environment, can be much stronger in certain work groups than in others due to the implications of senior (colleagues and self-employed colleagues) or minor (employees) social support of emotional ties, trust, and solidarity [29,74].

Similarly, Latino self-employed were ranked in some earlier studies (e.g., [75-78]). Several studies have supported the JDCS model in the context of freelancers (e.g., $[40,79])$, but there are no studies that analyze entrepreneurship in Ecuador with this model.

Therefore, in relation to these variables included in the JDC model, four situations that affect psychological well-being can be approached: (1) The self-employed, with a workplace characterized by a wide margin of freedom of decision to propose and implement changes in their company, and with the power to assume risks that may determine growth, higher productivity or, in extreme cases, business failure; this can be defined as active work, where high labor demands and high control at work for decision making prevail [30,80], it assumes that the self-employed perceive their jobs as more stressful and mentally exhausting since they work longer hours, have less free time, and more responsibility for their own jobs and income, as well as those of their employees, which would lead to greater mental health problems and a lower level of general health. (2) The characteristics that define the work environment with low demands in the workplace and high control in the activities they carry out generate a higher level of well-being; in this case, having 
freedom of action can increase or reduce the intensity in productivity and effectiveness of its results. (3) High labor demands and under control are related to tensions at work, which could negatively affect the well-being and health of the self-employed. (4) When the activity is generated in an environment of low demand and under control, it is present in a passive work environment, stimulating a decrease in work activities and less ability to solve problems in general [30], which is characterized as routine or boring, and it also leads to health risks [81].

\subsection{Job Demands, Control, Support and Well-Being in Entrepreneur Context}

The self-employed labor sector is a fundamental pillar of a welfare society. From the perspective of the self-employed, the perception they have of their work, which is defined in terms of usefulness for society, is of major consideration. This concept can substantially increase motivation and effort related to job performance [82,83]. In fact, previous research has indicated that people have a higher degree of well-being when completing jobs that they consider useful for society [84]; in addition, the importance of work is positively associated with well-being $[85,86]$. The well-being of workers is essential for the sanitary condition of any community [87]. Balancing the well-being of the self-employed is crucial for sustainable development [88], since well-being impacts the quality of service and the development of the area [89], and with a low sensation of well-being, the possibilities of suffering health problems increase [40]. Following this idea, the nature of autonomous work embodies the process of self-realization of the worker's human potential through bold, authentic, and self-organized activities that can lead to the fullness and functionality of the human being [63].

The work demands of the self-employed worker are dictated by the economic context, which can cause a decline in health [90] due to factors such as stress and depression [40]. This work group is characterized by high work demands, both physical and psychological. The situation regarding the physical demands of the self-employed reflects intense work activities and stressors [91,92], such as more working hours and lower wages [51,93], excessive work effort and an unpredictable business environment, which are factors that cause a reduction in well-being [15]. In fact, self-employed workers are not under the legislative context of employment in terms of hours of work and job security [94]. Regarding the psychological demands, the self-employed must make urgent and critical decisions for the development of their company [95] and must carry on with their work with a higher intensity than most workers [96-99]. The self-employed has been associated with better organizational performance [100] and persistence due to entrepreneurship [101]. In line with the above, it is suggested that having high levels of autonomy could mitigate the possible risks of work stress if this autonomy is not associated with an excessive dependence on self-employment [102]. From the perspective of job control, there are studies that conclude that this dimension is positively related to business abandonment when the self-employed does not detect support from their environment [103]. Specifically, Cortés et.al. [75] report that people who are self-employed have a lower degree of satisfaction than people employed in Latin America.

\section{Research Hypothesis}

From a theoretical point of view, well-being conceptualizes the valuation that people perceive of their own quality of life [104,105], including their work situation, personal conditions, values, goals, and aspirations of workers. From this perspective, the academic literature should focus on the analysis of the working life of individuals, and this should be a basic concern for the society, especially in this troubled post-COVID-19 era [106]. The job demand control model (JDCS) identifies three variables of working conditions: employee demands and control of activities and social aspects [74,107]. These theoretical structures identify the key dimensions of work activity, that is, the organizational or psychological demands (work demands), the independence that employees enjoy with respect to their 
functions, the tasks and skills required for this position, and finally, the social support of the supervisor and the worker's colleagues.

The present research aims to explore the well-being of Ecuadorian self-employed workers, analyzing the three variables related to work stress described above. In accordance with the reference framework described in the previous paragraphs and based on the literature review, the following research hypotheses are proposed:

Hypothesis 1 (H1). The high job demands faced by the self-employed influence their well-being.

Hypothesis 2 (H2). The high labor control also affects well-being.

Hypothesis 3 (H3). The social relationships with their work colleagues faced by the self-employed that is the perceived social support are a cause of their well-being.

Hypothesis 4 (H4). The high labor control faced by the self-employed will reduce the effects of job demands on well-being.

Hypothesis 5 (H5). Supervisors/co-workers will reduce the effects of job demands on well-being.

The following Figure 1 summarizes the theoretical model and research hypotheses.

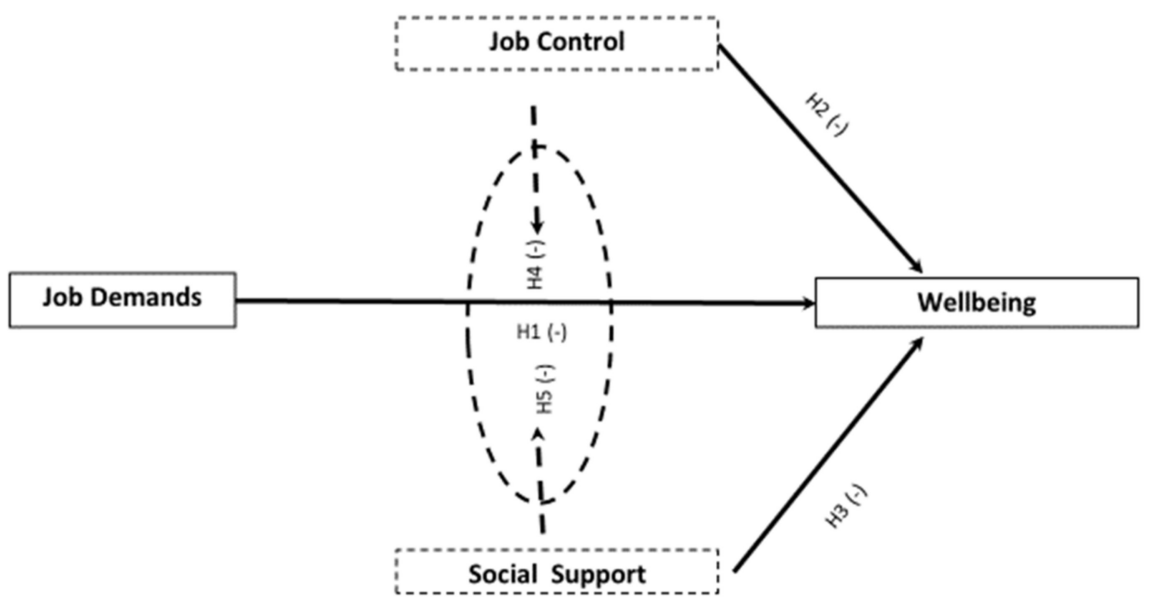

Figure 1. Theoretical model.

\section{Methodology}

\subsection{Sample Data}

The population under study is the self-employed over 18 years of age, residing in the province of Manabí-Ecuador, who carried out an independent activity, be it commercial or services, and who had at least the RISE (Ecuadorian Simplified Registration Regime), which implies voluntary registration in the Internal Revenue System (SRI).

The population is formed by all the self-employees in the region of Manabi (Ecuador), as recorded in the labor department. Although the applicability of the results is possible in this geographical area, the Andine region, which is in Ecuador, Colombia, Peru, and Bolivia, contains many environments with similar characteristics, considering both the physical and the social conditions, so it would be possible to extend the results to a broader area. However, the characteristics of entrepreneurs should be very different. Furthermore, Ecuador is one of the Latin American countries with the most inequalities in terms of economic growth within its own territory and in relation to the rest of the Latin American countries [108]. Following this idea, Manabí, according to the latest census [109], is the third province in terms of population with 1.37 million inhabitants; it is considered an important administrative, economic, financial, and commercial pole of Ecuador, whose main activities are focused on commerce, livestock, industry, fishing and highlighting, in addition, the agricultural sector 
in rural areas as well as tourism, mainly because of its extensive and attractive beaches. Politically, it is divided into 22 cantons, which are distributed over an area of $18,940 \mathrm{~km}^{2}$, and it has the highest rate of informal self-employed, specifically $58.5 \%$ compared to the rest of the Ecuadorian provinces [110]. This type of self-employed is in the front line in terms of economic and health risks due to COVID-19 [111].

The information was collected using a questionnaire together with a personal interview with each self-employed person of the Manabí. The questionnaire was prepared in October 2020. The data were collected through a questionnaire, which was given to the self-employed. To ensure the validity and construction of the questionnaire, the questions used were based on those of previous similar studies in Europe e.g., [87,112].

The sixth EWCS survey was taken as a reference. This survey is periodically issued by the European Foundation for the Improvement of Living and Working Conditions (Eurofound), in which information related to the employment and health situations of employees and independent workers is exposed at the European level. A structured questionnaire was chosen as the most appropriate data collection method for this study. In an initial phase, the data collection was carried out with a pilot sample to collect the information following the objectives of the research, and its internal consistency was rigorously analyzed. A self-administered closed questionnaire was selected as the most appropriate method of data collection, and items were chosen from similar previous studies (e.g., $[113,114])$. Thus, the validity of the survey was guaranteed and, finally, two groups of experts (researchers from the management and employment areas) evaluated and helped to choose the elements. Therefore, the validity of the constructed elements was verified twice. Before completing the questionnaire, the self-employed were informed about the academic purposes and the anonymity of their responses. The consent to carry out the questionnaire was verbal. At all times, the anonymity of the self-employed was guaranteed.

The questionnaire was organized into seven dimensions that focus on the quality of work conditions and their work environment such as skills and discretion, physical environment, work intensity, quality of work time, social environment, prospects and earnings. The different variables were measured on a 5-point, where 1 means totally disagree and 5 means totally agree. In a second phase of the survey, the interviewer asked the self-employed for their cooperation and provided information on the objectives of the research. The self-employed completed the survey anonymously and with full autonomy.

The information for the present study was compiled based on a survey applied to a sample, in which the 90,026 registered companies that were distributed in each canton in the province were considered as the population to be investigated; these data are determined by the official statistical body [115]. In this case, for the application of the surveys, we proceeded according to the number of records for each canton, where a higher value of records represents the application of a greater number of surveys, through a proportional allocation, and a random selection in each canton.

To establish the possible relationship between well-being and JDCS conditions, the analysis has been limited to small businesses, with or without employees in Manabí, for whom their work activity represents the main stream of income and family support. The survey based on the European Conditions Working Survey, (EWCS), which was applied to selfemployed workers, obtaining a sample of $n=1033$ observations. Table 1 reflects with a simple random sampling, on estimating proportions, the expected error would be less than 0.03 with a confidence of 0.95 . As the design has been stratified, it is possible to expect better results in the precision of different estimates. Of course, when dealing with part of the whole population, this confidence would be smaller. 
Table 1. Experimental design.

\begin{tabular}{cc}
\hline Variables & Data \\
\hline Population Size & 90,026 \\
Error & $3 \%$ \\
Confidence & $95 \%$ \\
Sample size & 1033 \\
\hline
\end{tabular}

In relation to the analysis of the sample, of the total of self-employed persons analyzed, $58.2 \%$ are men, compared to $41.8 \%$ women. Considering the level of study of the respondents, $14.7 \%$ claim to have primary studies, $57.4 \%$ secondary, $25.1 \%$ at university level, and only $0.8 \%$ had obtained doctorates. If the business operating time is analyzed, $2 \%$ affirmed that it was less than 3 months, $6.8 \%$ reported between three and six months, $6.8 \%$ reported between six months and a year, $9.5 \%$ reported between one and two years, $20.5 \%$ reported between two and five years, and $56.4 \%$ reported over five years.

The sixth EWCS survey was taken as a reference. This survey is periodically issued by the European Foundation for the Improvement of Living and Working Conditions (Eurofound), in which information related to employment and health situations of employees and independent workers is exposed at the European level.

Table 2 reflects the EWCS recorded variables, according to the constructs proposed.

Table 2. Variables used from European Conditions Working Survey (EWCS).

\begin{tabular}{|c|c|c|}
\hline Construct & Concept & Questions Codes and Text \\
\hline \multirow{7}{*}{ Job Demand (JD) } & \multirow{4}{*}{ Physcal Job Demands } & JDF1 Noises so loud you have to raise your voice to talk to people \\
\hline & & JDF2 High temperatres, either inside the buiding or outside \\
\hline & & JDF3 Breahig fumes, such as solvents or thinners \\
\hline & & $\begin{array}{l}\text { JDF4 Handling or having direct contact with materials that can be } \\
\text { infectious, such as waste, body fluids, laboratory materials, etc. }\end{array}$ \\
\hline & \multirow{3}{*}{ Psychological Job Demands } & $\begin{array}{c}\text { JDPS1 Being in situactions that may upset you emotionally } \\
\text { (handling angry customers) }\end{array}$ \\
\hline & & JDPS2 Work at high speed \\
\hline & & JDPS3 Perform complex tasks \\
\hline \multirow{3}{*}{ Job Control (JC) } & \multirow{2}{*}{ Job Control Skill Application } & JCSA1 Solve unforseen problems yourself \\
\hline & & JCSA2 Perform monotonous tasks \\
\hline & Job Control Authority Decision & JCDA I make the most important decisions about how to run my business \\
\hline Social Support (SS) & Authority Support & SS It encourages and supports them in their development \\
\hline
\end{tabular}

In this case, the classification has been made into three main groups according to the dimensions of work demand (JD), job control (JC), and social support (SS), each group with its respective variables, which are structured according to the application of a probabilistic binary logit model, where the predictive results have been obtained using a Jackknife method developing a specific program based on EViews 10 econometric software. The process involves estimating $n=1033$ models, each with 1032 data, and classifying the remaining case to evaluate the predictive power of the procedure. As an alternative method, artificial neural networks (ANN) have been used in this classifying process as an alternative to logit models; the predictive power of the ANN has been evaluated using a large subset of observations not included in the training set. In both cases, the impact on the well-being of the self-employed has been linked to the proposed exogenous variables, JD, JC, and SS, with the corresponding statistical testing.

\subsection{Questionnaire and Scales}

Latent variables, proposed in the SEM model, are associated to numerical variables from the EWCS. 
1. Job Demand (JD) is associated with seven observable variables, which are classified into two specific fields: demand for physical work and psychological demand. The first group is linked to four variables obtained from questions of the type, "To what extent are you exposed to ... ?" asking data about the conditions of the workplace of the self-employed. These are related to the physical environment (vibration, noise, high temperatures) and exposure to biological and chemical risks (breathing fumes, gases, handling products and chemicals and materials infectious such as waste, body fluids, laboratory materials, or similar). The second group is made up of three variables, and they are focused on questions such as: "To what extent does the development of your activities in the business imply ... ?", or "Could you tell me if your job depends on ... ?", and "The work in your business/company implies ... "; those questions allow arguing about the intensity of work, the quantitative demands of work, the determining steps in interdependence, and the emotional burdens due to the demands at the workplace.

2. Job Control (JC) is associated with three observable variables, which are classified into two groups: application of activities and decision authority. The first group is composed of two variables, and they are disaggregated from the question "Generally, work in your business/company implies ..." This construct refers to the domain and work skills in the performance of the work activities (monotonous or complex) to solve unforeseen problems, and to the flexibility adopted for the implementation of new ideas. The second group, composed of a variable, is generated from the question, "To what extent do you agree or disagree with the following statements?", from which the scope of authority is established; it is linked to the autonomy to take decisions regarding the performance of their activities, the working methods, the speed with which they are carried out and the productivity to be achieved.

3. Social Support (SS) is made up of an observable variable, which is focused on the question, "To what extent do you agree or disagree with the following statements?", including, You respect your employees ...", on which the behavior assumed as boss within the workspace is argued, the ability with which you incur to motivate and encourage your staff to work as a team and achieve the proposed goals, as well as contribute to the effectiveness of work by supporting them in their development and work performance. From this scope, the position of the boss in support of their collaborators is analyzed, understanding this as a perceived condition of harmony and well-being in interaction with their collaborators and also with their autonomous colleagues, because many of the respondents participate in the same branch of activity.

4. Well-Being (WB): The well-being variable is linked to different factors that include questions obtained from the EWCS and related to a positive state of the autonomous individual, such as, "How have you felt since you started your business?" These questions treat different aspects of feelings in the workplace; these include concepts such as the happiness sensation in the workplace, feeling in a good mood, or calm and relaxed; also, some others aspects such as feeling calm and relaxed, active and energetic, woken up fresh and rested, or interested things in daily life, which are conditional to the fact that the happiest people have a job that provides them with satisfying experiences [116], but that also from an integrative perspective that can reflect positive and negative affective conditions of an individual, and the corresponding psychological functioning. The latter is analyzed from the perspective of work control (autonomy) exercised in their work performance.

The items used in the construction of the well-being variable are shown in Table 3. Of the total of cases analyzed, 53\% stated that they reached an adequate level of well-being, compared to $47 \%$, who are affected by low well-being. If the results are analyzed by the sex of the individual, it is observed that the proportion of men who consider themselves satisfied is somewhat higher than this figure for women, with a differential of $6.6 \%$. 
Table 3. Well-being-related variables.

\begin{tabular}{ccc}
\hline Variable & Codes & Questions \\
\hline \multirow{3}{*}{ Wellbeing } & WB1 & Feelings of happiness and good humour \\
\cline { 2 - 3 } & WB2 & Feelings of calm and relax \\
\cline { 2 - 3 } & WB3 & Feelings of active and energetic \\
\cline { 2 - 3 } & WB4 & Feelings of the freshness and rest \\
\hline
\end{tabular}

A description of the variables used to test the hypotheses discussed above is shown in Table 4. Regarding the averages of the factors of the JDF dimension (four variables), where the minimum values range from 1 to the maximum values of 4.50 , it is observed that the global mean is 2.588 for the set of variables, having a standard deviation of 0.65 . This means that the impact on well-being is potentially higher, controlling factors such as noisy environments, high temperatures, breathing vapors harmful to health and the handling of infectious and polluting materials are considerably present at work. Regarding the averages of the JDP dimension (three variables), which range between 1.33 and 5; their global mean is 3.27 and its standard deviation is 0.769 . Therefore, self-employees are potentially little or somewhat exposed to factors that can annoy them, such as angry customers, performing complex tasks, and working at high speed, which can potentially affect their well-being.

Table 4. Description of the variables.

\begin{tabular}{lcccccc}
\hline \multicolumn{1}{c}{ Variables } & & \multicolumn{5}{c}{ Parameters } \\
\hline \multirow{2}{*}{$\mathrm{N}$} & & JDPH & JDPS & JCDA & JCSA & SS \\
\cline { 2 - 7 } & Lálid & 1033 & 1033 & 1033 & 1033 & 1033 \\
\hline Media & & 0 & 0 & 0 & 0 & 0 \\
\hline Dev. Deviation & & 2.60026 & 2.30799 & 0.8388 & 1.24647 & 1.42108 \\
\hline Variance & & 6.761 & 5.327 & 0.704 & 1.554 & 2.019 \\
\hline Asymmetry & & -0.378 & 0.335 & -2.639 & -0.262 & -0.692 \\
\hline Standard error of skewness & & 0.076 & 0.076 & 0.076 & 0.076 & 0.076 \\
\hline \multirow{2}{*}{ Percentiles } & 50 & 8 & 8 & 4 & 5 & 3 \\
\cline { 2 - 7 } & 75 & 11 & 10 & 5 & 6 & 4 \\
\hline
\end{tabular}

In relation to job control, for the two variables of JCSA, there is a global mean of 4.56 and a standard deviation of 0.839 . In this same line of the JC, the average of JCDA (associated to just one variable) is 2.68 and the standard deviation is 0.623 . In this case, this situation represents that the self-employed persons' decisions are carried out by themselves, as they have the freedom to choose what should be done in each circumstance. Therefore, they have full control to run their business, and they tend to feel fine, which affects positively their well-being.

In the case of the SS dimension, it is associated with a variable with mean 3.56 and standard deviation of 1.421. In this case, it is presumed that social support is generated in the microenterprise field, from the owner to his collaborators, but in addition, it is manifested with his autonomous relatives because most of them share the same branch of activity; this could be referred to as "harmonious work" with their collaborators and work colleagues, and this situation leads to think that the SS is somewhat separated from the average and moderately affects positively their well-being. 
Table 4 presents the description of the variables used in the model proposed. The JDPH construct is linked to four variables related to physical job demands, the JDPS construct is linked to three variables, while the JC construct is linked to two variables of job control skills and one of authority in the decision process. As the original variables are considered numerical valuations, the corresponding descriptive parameters are presented.

\section{Results}

To assess the validity of the research hypothesis, two types of modeling were used: logit models and artificial neural networks. The endogenous variable to be analyzed is the well-being, which is transformed in a binary variable denoting an adequate level of well-being or the lack of it. It was specified as dependent on the three constructs JD, JC, and SS. The logit binary choice model [117-119] allows us to analyze the influence of causal exogenous variables on a binary endogenous variable. Subsequently, and in order to carry out the testing of the proposed hypotheses, the corresponding Z-tests were applied with positive results. Then, an artificial neural network is estimated to corroborate the effects of the three constructs introduced in the logit model, to forecast the well-being of the self-employed. Artificial neural networks (ANNs) are used in numerous classification problems, as with the binary variable representing the presence or absence of well-being. In the ANN, wellbeing (WB) constitutes the output layer, while the constructs are included in the input layer. There are some alternative multivariate techniques that could be applied: discriminant analysis or support vector machines. Finally, the coefficients obtained by both methods are evaluated in order to determine the priorities that each self-employed grants in the importance of their welfare situation.

\subsection{Binary Logistic Regression Model}

The binary variable $W B$ is linked to a clear feeling of well-being in the self-employed. In the sample, 547 (53\%) consider themselves enjoying a high or very high well-being, and 486 received lower marks when the measured variable is up to two points. Over this, the consideration is of high level of well-being.

The estimated model is presented in Table 5. As can be seen, all the p-values in the Wald test are very low, less than $2.5 \%$, and in most of the cases, they are less than $0.1 \%$. The signs of every coefficient is what could be expected, as they indicate the sense of the influence of each variable on the probability of obtaining a high degree of well-being.

Table 5. Estimated model.

\begin{tabular}{ccccc}
\hline Variable & Coefficient & Std. Error & Z-Statistic & Prob. \\
\hline C & -1.028 .068 & 1.197 .087 & -8.588 .084 & 0.0000 \\
JDH1 & 0.458283 & 0.131056 & 3.496 .844 & 0.0005 \\
JDPH2 & 0.367339 & 0.104553 & 3.513 .428 & 0.0004 \\
JDPH3 & 0.626949 & 0.168813 & 3.713 .876 & 0.0002 \\
JDPH4 & 0.753204 & 0.164460 & 4.579 .854 & 0.0000 \\
JDPS1 & 0.222068 & 0.065489 & 3.390 .902 & 0.0007 \\
JDPS2 & 0.266075 & 0.064430 & 4.129 .675 & 0.0000 \\
JDPS3 & 0.383952 & 0.083450 & 4.600 .956 & 0.0000 \\
JCSA1 & 0.196626 & 0.086215 & 2.280 .660 & 0.0226 \\
JCSA2 & 0.299025 & 0.085704 & 3.489 .035 & 0.0005 \\
JCDA & 0.191025 & 0.086617 & 2.205 .386 & 0.0274 \\
SS & 0.651075 & 0.270967 & 2.402 .784 & 0.0163 \\
JDF*SS & -0.054312 & 0.026392 & -2.057 .879 & 0.0396 \\
\hline RMF2 0.2368 & & AIC $=1.080409$ & & BIC $=1.14258$ \\
\hline
\end{tabular}

It should be noted that the fundamental principles of the JDCS model are confirmed. Labor demands, work control, and social support are related with the response variable, that is, the WB indicator. However, these results should be viewed with caution because the statistically significant variables are those related to noise $\left(J D P H_{1}\right)$; high temperatures 
$\left(\mathrm{JDPH}_{2}\right)$; the presence of vapors $\left(\mathrm{JDPH}_{3}\right)$; and the manipulation of infectious materials $\left(\mathrm{JDPH}_{4}\right)$. In relation to psychological demands, the significant variables are related to relation with clients $\left(J D P S_{1}\right)$; speed when carrying out tasks $\left(J D P S_{2}\right)$; the possibility to solve problems $\left(J D P S_{3}\right)$; ability to make decisions about how to run the business $\left(J C S A_{1}\right)$; ability to make decisions $\left(J C S A_{2}\right)$; collaborator support (JCDA); and social support (SS). The interaction term is a decreasing influence of SS that occurs in the opposite direction to the JDFs variables.

An examination of each of the individual components shows that physical demands are more important than psychological demands in predicting WB in self-employed Ecuadorians.

To measure the forecasting power, the two-way classification table usually obtained with the sample data used to estimate the logit model has been modified to avoid using the same sample data employed in the estimation process to classify this set of data. A jackknife method, which is usual in discriminant analysis, has been introduced: leaving one case out of the sample, a logit model is estimated and then used to classify the omitted data, to avoid the bias introduced if this case had not been left out of the estimation procedure. The process is repeated $n=1033$ times, leaving out a different case each time. The obtained classification table (using a cutpoint of 0.5 in the classification) is presented in Table 6, where $74 \%$ of the cases are well classified with respect to the well-being variable. The computational procedure to use this jackknife method is not implemented in the SPSS package used, so a program was developed with the econometric software EViews. When using the model to forecast the well-being of the sample data, the following classification table is obtained.

Table 6. Forecasting power with the logit model.

\begin{tabular}{cccc}
\hline Variables & WB $=\mathbf{0}$ & WB $=\mathbf{1}$ & Total \\
\hline $\mathrm{P}(\mathrm{WB}=1) \leq 0.5$ & 354 & 134 & 488 \\
$\mathrm{P}(\mathrm{WB}=1)>0.5$ & 134 & 413 & 545 \\
Total & 486 & 547 & 1033 \\
\% Correct & 72.84 & 75.50 & 74.25 \\
\hline
\end{tabular}

Using, as an alternative method, a discriminant analysis procedure, the proportion of correct classifications is well below those obtained with the logit model.

\subsection{Artificial Neural Networks}

In the neural network presented, the input layer includes the same exogenous variables as those used in the logit model; there is a single hidden layer with five neurons and an output layer with the binary variable $W B$. Thus, the topology proposed is a multilayer perceptron-type (MLP) network $(11+1,5,1)$. In the graph (Figure 2), there are two bias variables ('Sesgo') to incorporate a constant when carrying out the linear combinations of the output of each layer. The activation information, which controls the output of each neuron, has been the hyperbolic tangent in the hidden layer.

In estimating the network, practically $80 \%$ of the data have been used, which forms the so-called "training set", and the rest have been used to validate the predictive capacity of the network, forming the "test set". In the logit model, there was a training set of 1032 observations and a test set with the remaining case, although, with the jackknife method, 1033 models were estimated, leaving out a different case in each of them. This strategy is not possible with neural networks due to the computational load it would imply, and the usual procedure is the one employed to divide the sample in the two sets of data.

The summary of the model and its classification table are presented in Table 7 . The network model provides a proportion of correct predictions higher than that obtained with the logit model: $79.3 \%$ in the test set, improving the predictive capacity in the two categories of the $W B$ variable. 


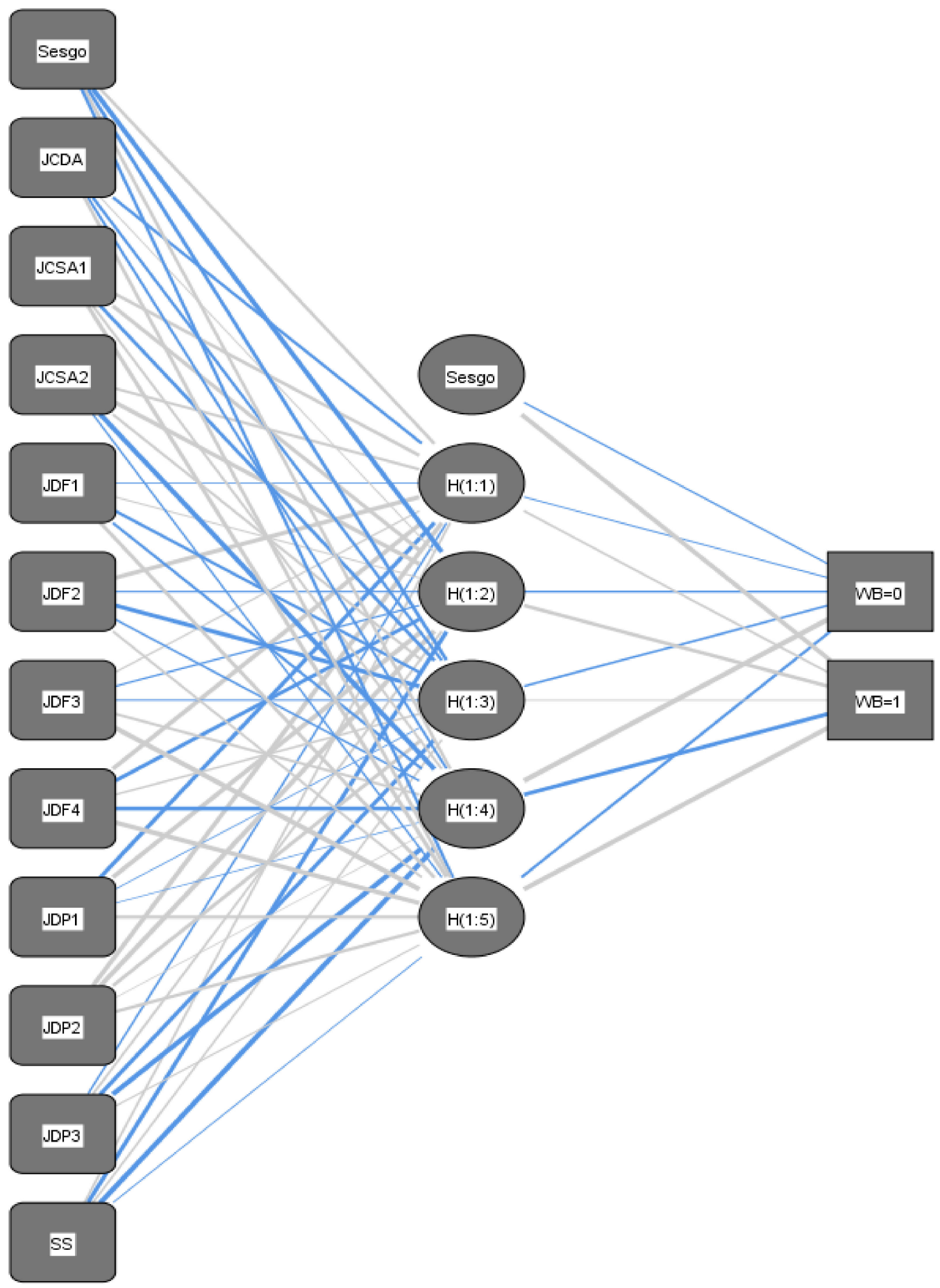

Figure 2. ANN topology.

Analyzing the importance that each of the explanatory variables confers to the prediction of the $\mathrm{WB}$, it is observed that there are several factors linked to the job demand physical construct that present the greatest joint contribution, which is followed by those associated with job control decision authority. In lesser importance are those factors related to physical demands and job control for both the skill application and authority decision, and for social support.

The estimated parameters for the ANN are presented in Table 8. 
Table 7. Forecasting power with the artificial neural networks (ANN).

\begin{tabular}{ccccc}
\hline Example & Observed & \multicolumn{3}{c}{ Predicted } \\
\hline \multirow{3}{*}{ Training } & & No & Yes & Percentage Correct \\
& No & 265 & 75 & $77.9 \%$ \\
& Yes & 103 & 285 & $73.5 \%$ \\
\multirow{3}{*}{ Test } & Overall percentage & $50.50 \%$ & $49.5 \%$ & $75.5 \%$ \\
& No & 114 & 32 & $78.1 \%$ \\
& Yes & 31 & 128 & $80.5 \%$ \\
\hline
\end{tabular}

Table 8. ANN parameters.

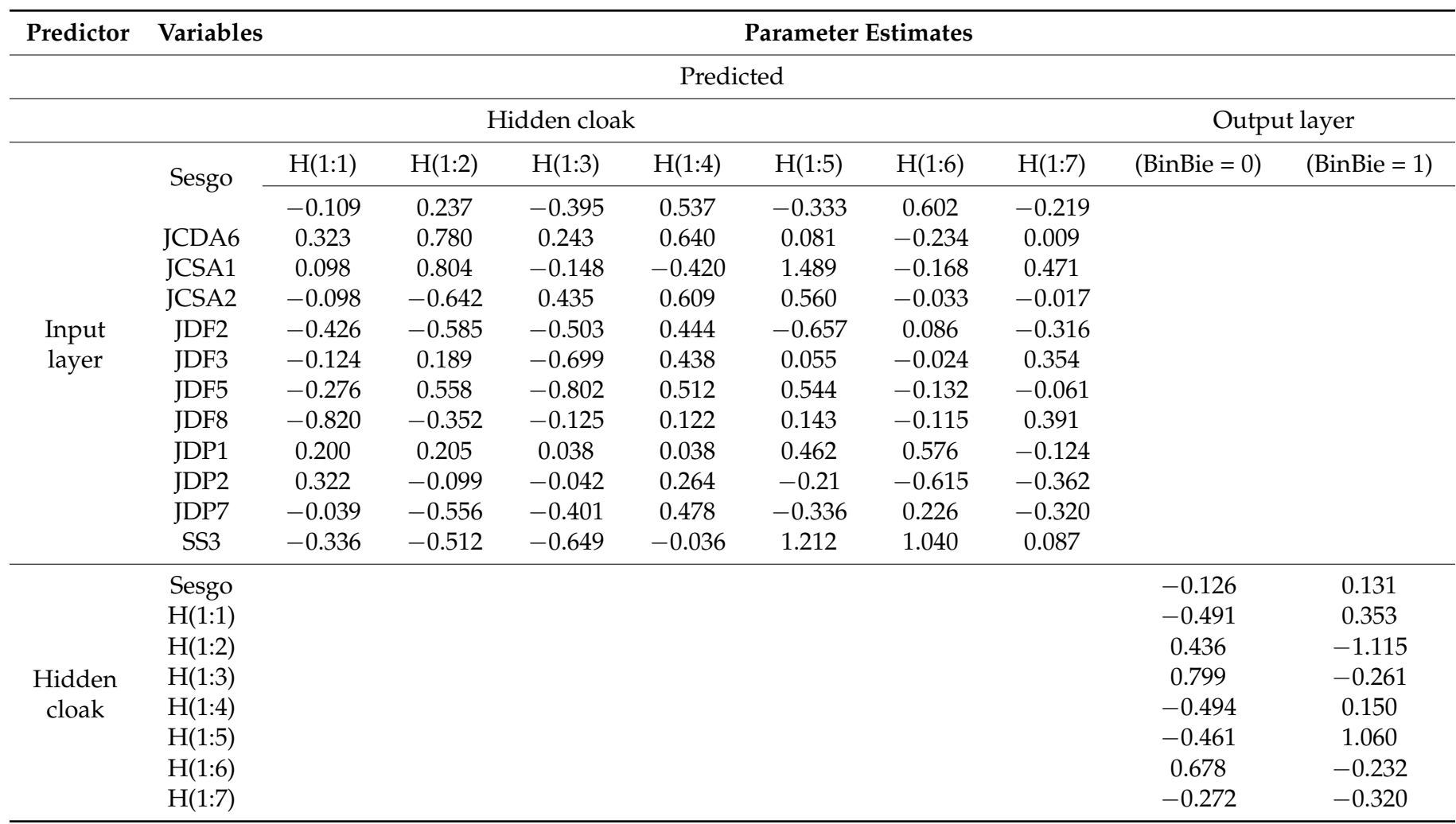

To review the hypotheses, the coefficients obtained from the explanatory variables and their exponentials, called ODDS ratios, will be used. The analysis of these ratios allows comparison with each other in order to know which variables have a greater or lesser influence on the probability of occurrence of the event, i.e., be satisfied

Thus, when these ratios are greater than unity, the probability of occurrence of the aforementioned event increases; on the contrary, if they are less than unity, they reduce said probability. In the case of the latter, it is convenient to calculate the inverse in order to compare it with the rest of the ODDS ratio.

As can be seen in the estimation of the logistic model and the neural network, it is confirmed that the variables linked to the analyzed factors are significant. Therefore, it can be contrasted that the job demand (physical and psychological), job control (authority decision and skill application), and SS constructs are directly related to the level of WB.

In all cases, the associated coefficients show positive signs and ODDS ratios greater than one. Thus, it can be specified that an increase in the value granted to each and every one of the analyzed characteristics improves the worker's level of well-being, keeping the rest of the factors constant. 
More specifically, and analyzing each of the dimensions separately, it is observed that the factors linked to job demand (physical and psychological) of the original linked variables were measured on a five points, with 1 being social aspects favoring dissatisfaction, and high values of the variable relating to highly motivating social situations. It is observed that the ODDS ratios oscillate between 1.2 for the case of JDF2 and 1.7 for JD4, which indicates when the associated factor increases by one unit, the probability of manifesting well-being increases by $20 \%$ or $70 \%$ respectively. Likewise, it is observed that the ODDS ratios, in the case of psychological demand, fluctuate between 1.25 for JDP1 and 1.48 for JDP3, which means that an increase in one unit of these factors can be considered an increase associated with well-being in 25 or $48 \%$. This statement allows us to know what factors influence to a greater extent the improvement of well-being.

In relation to the factors linked to job control (Skills and authority decisions), it is clear that the original variables linked to these factors were measured, where 1 represents a negative situation of well-being and 5 represents a condition of positive impact. The ODDS ratios in relation to these factors are focused on 1.26 for JCSA1 and 1.35 for JCSA2, which implies that an increase in one unit of these factors entails the probability that a certain level of satisfaction associated with well-being will be generated in individuals in $26 \%$ to $35 \%$, respectively; similarly, the ODDS ratio appears with a result of 1.22 for the JCDA factor, which indicates that an increase in one unit, the marginal variation of this factor, with respect to welfare, will increase by $22 \%$. In this case, the results are also significant, which implies taking the measures to achieve greater advantages of the job control.

The factors related to the social support dimension (support from authority) were measured on the other variables with 1 being social aspects favoring dissatisfaction and high values of the variable, which are social situations very motivating for its estimation; the SS factor appears with an ODDS ratio of 1.17, which means that an increase of one unit in this factor will have a marginal variation of $17 \%$, which represents that the support of authority generates a certain level of well-being, which is significant, but which will allow focusing the conditions of social support with greater direction in this sector.

\section{Discussion}

The purpose of this work was to analyze the different characteristics of the working conditions of the Ecuadorian self-employed and whether these conditions influence their well-being to create the basis for an adequate reconstruction of the sector. The selfemployed are considered as key agents in economic growth [120]. According to Koellinger and Thurik [121], entrepreneurs are agents of change and economic development, who anticipate and even trigger economic growth, but in turn, many business owners carry out only marginal activities and escape unemployment through entrepreneurship. Following this idea, according to Audretsch and Keilbach [122], there are key factors that relate entrepreneurship with discriminatory variables in each region such as ethnicity, language, religion, policies, and the quality of institutions (for example, corruption, public freedom ... ), which is why they are a priority in policies to promote economic development through actions based on entrepreneurship [40,94,123]. In general, cross-cultural results generally support the idea that job stress and available resources differ between cultures [124]. Curiously, little research on culture and work stress and well-being has been done in the South American context.

The occupational notion of self-employment emphasizes that this sector's workers manage (beside being owners) their business at their own risk and expense [125]. Some authors classify self-employment as stressful, and it is possible that this represents a reality according to the functions or roles that they perform. However, there are studies showing that the Ecuadorian self-employed, where precarious working conditions and the physical environment in which it unfolds, is not the most appropriate, nor does it compete with the entrepreneurial spirit of developed countries [126]. This is because self-employees work in a complex and uncertain environment, working long hours and having to perform a wide 
range of tasks [127]. There are some attempts describing the labor market in Latin America using objective indicators such as wages or hours of work [128,129]. There are studies that link wellness and health [130] to self-employment [131]. Following this idea, the literature shows that from intercultural management, analyzing countries such as Canada and Pakistan, the self-employed experience lower levels of work-related well-being, indicating that the self-employed spend less time with the family than employed persons. Jamal and Cardon and Patel [132,133] show that the self-employed have more stress than employees but that this situation has a positive impact on incomes despite a negative impact on physical health [133]. In agreement with [134], self-employed women reported poorer physical health and well-being than men. These job stressors are associated with mental health problems. Torrès and Thurik [135] add that the effects that entrepreneurs have on wellbeing are cyclical and can have dynamic effects, where factors such as the euphoric start of a company give way to the monotony of running a business. Specifically, Cortés et al., Graham and Felton $_{\mathrm{ab}}[75,136,137]$ report that people who are self-employed have a lower degree of satisfaction than those employed in Latin America. In Latin America, there are some research studies analyzing labor force status as a determinant of individual's subjective well-being, finding different results. Using data derived from the Latinobarometro survey of 2000 and 2004, the work of Graham and Felton ${ }_{\mathrm{ab}}$ and Graham and Pettinato and Lora [136-139] differentiated between employed, self-employed, and other non-active labor status, showing that in Latin America, they enjoy on average less well-being than the employed, and they also argued that workers in the self-employment sector choose this labor option due to the absence of more secure employment opportunities and live a precarious existence in the informal sector.

To examine this issue among the self-employed, the current study adopts the JDCS model as a frame of reference, developing several logistic regression and ANN models that attempt to explain the effects of labor demands, job control, and support.

First, with respect to Hypothesis 1, a significant effect of physical and psychological demands on WB is confirmed. The physical demands that affect the self-employed the most are loud noises, high temperatures, breathing vapors, handling or having direct contact with infectious products, such as waste, body fluids, laboratory materials, and psychological ones related to angry customers and the speed at which they must perform tasks, and complex tasks. Boyd and Gumpert [140] have shown that most selfemployed encounter physical problems at least once a week (such as indigestion, insomnia, and headaches), mainly because they feel they are responsible for their business and their employees. These job demands are independent of whether the company is performing well, suggesting that the general daily tasks and challenges self-employed must handle, and the accompanying workload in particular, increase the likelihood of experiencing stress. Boyd and Gumpert and Eden and Harris et al. [140-142] show that self-employment, despite its numerous other advantages, does not provide workers with the greater psychological benefits promised by the American dream. According to the World Health Organization, low work well-being is one of the most important causes of absenteeism, turnover, and low performance in the workplace [143], which in the case of the self-employed worker is related to the closure of the exercise. The physical and psychological demands that self-employed workers face are well known, which is why they have to work longer working hours and have less time for leisure activities than salaried workers. Millán et al. [144] identify different types of job satisfaction between self-employed and employed workers, so much so that Millán et al. [145] suggests that when the figures mentioned above are mixed (self-dependent), they are characterized by less control of work than self-employed workers, greater demands than paid employees and, in general, worse job outcomes than both. Specifically, in relative terms compared to nearby countries such as Peru, Colombia, or Chile, Ecuador has some lags that make it difficult to establish and stay in business over time. On the other hand, the country has comparative advantages regarding infrastructure and entrepreneurial intent. However, the country has limitations in relation to the regulatory environment, regulations around 
opening and closing businesses, online businesses, and innovation [146,147]. For other categories of self-employment, the economic insecurity and lack of stability associated with precarious jobs prevent people from considering their occupation as an opportunity for personal growth or a source of well-being. This latest evidence agrees with the findings of Graham and Felton $_{\mathrm{ab}}[136,137]$ and Graham and Pettinato [138].

The results of our study indicate that the self-employed experience a similar tension due to physical and psychological demands, although the physical ones are slightly higher, which is perhaps because most of the activities carried out by the self-employed in Ecuador require a great physical effort for the economic activities to which they are engaged. Similarly, the stress they suffer in their businesses includes family and social obligations; although family demands are not necessarily negative, they can turn into work-family stress when there is a disparity between work and family demands [148]. Buttner [149] delves into stress management, indicating that it may be due to conflicts in the balance of work time, which is why it is suggested that entrepreneurs use coaching to relieve this tension at the end of the day. This is the result of having a limited amount of time and attention to give to these two demands due to factors such as atypical hours that include shift work, weekends, and night duty. These factors cause a decrease in well-being that manifests itself as less organization, exhaustion, work stress, and dissatisfaction [62].

Hypothesis 2 of this research was examined in a second phase aimed at demonstrating the effect of labor control on well-being, and Hypothesis 4 of this research was examined in a second phase intended to demonstrate the modulating effect of job control on well-being. The results of this study confirm that imposed problems, monotonous tasks, and decision-making affect well-being, which suggests that increasing adequate time management and perception of the risk derived from their activity will improve their mood, vitality, and interest in general, thus cushioning the direct effect that demanding work has on stress and that excess responsibility has on well-being. According to Prottas and Thompson [150] and Fasone and Puglisi [151], self-employment, whether as owner or self-employed, can allow individuals to achieve greater autonomy than they would have as employees. However, this study highlights the pressure associated with owning a small business, which detracts from the advantages of having autonomy, indicating that it is a double-edged sword. Furthermore, entrepreneurs have a higher level of stress in relation to the workload and not so much with the ambiguity or underutilization of skills, Buttner [149] indicating that this laboral category is characterized by heavy workloads, long hours, and a role self-established in the organization. For some Latin American self-employed workers, the autonomy and flexibility of their occupation seems to be considered an advantage compared to the employed. This is the case of the self-employed and entrepreneurs, and they coincide with the findings of Lora [139]. Other studies show that in Latin America, some workers may prefer to be self-employed rather than salaried workers because this generally means that they will not be contributing to social security systems (such as pensions, unemployment, or disability insurance) [152].

Therefore, this research empirically confirms that the lack of organization in the management of problems, as well as the need for an adequate risk analysis, causes the selfemployed person not to be able to make their own decisions, adapting them to an adequate work schedule in the workplace, which is time that allows the management of tasks with an increase in their dynamization. These aspects have a negative effect on the well-being of the self-employed. These results are in line with the study realized in Latin America by Salas et al. [153] and Greco et al. [144], who show that greater control in the workplace generates a better WB, especially when the individual is able to control their working hours and/or experiences an increase in calendar flexibility. For the health of the self-employed, their work activity is a priority that reduces their well-being and causes them to have health problems and stress greater than those of salaried employees [154]. This extreme and rigid dedication causes a high level of stress, poor health, exhaustion, a feeling of lethargy, and depersonalization [91]. Rauch et al. [155] and Semerci [156] reported that the recognition of business opportunities presented by the self-employed has been associated 
with knowledge and motivation. More recently, Nambisan et al. [157] emphasize the need to develop a greater understanding of self-regulation in entrepreneurship, mainly because self-control has not been considered as a key factor in the performance of the self-employed [158].

Hypothesis 3 of this research aimed to verify that social support benefits WB. This effect is confirmed in the support of colleagues; that is, the negative effect on WB is mitigated when the support of colleagues or collaborators is available. In conclusion, the physical and psychological demands derived from the figure of the self-employed in relation to WB are reduced if the self-employed have the support of their collaborators. Mette et al. [159] reached a similar conclusion by indicating that the emotional support that the self-employed have from their social network affects well-being through mechanisms related to culture. On the other hand, Brüderl and Preisendörfer [160] and Arregle et al. [161] show how the support of spouses, family, and friends increases the probability of survival and growth of the company. Social support is decisive in an occupation in which cooperative work occupies a prominent role. Caines et al. [162] and Casey [163] points out that in Japan, many older workers make the transition to self-employment with the support and approval of their organizations.

\section{Conclusions and Limits}

Two main motivations led us to focus our analysis on the Ecuadorian Manabí entrepreneur: his high weight in the Ecuadorian economy [164] and the new labor economic context that arose due to the pandemic in precarious terms [55]. The self-employed have been affected by the COVID-19 crisis in many different ways. It is no coincidence that in many countries, the self-employed are the ones that have been affected the fastest by the quality of demand and the political decisions and actions derived from the pandemic due, with the result of the closure of numerous businesses, despite this labor figure being key for the future growth of the countries [25]. From an economic perspective, Latin countries are used to facing negative external shocks; however, it is currently one of the areas most affected by the pandemic [25]. These circumstances pose challenges for the self-employed and for the future self-employed in terms of creating new economic activities [165]. Faced with this reality that we are in, we wonder how these circumstances will affect future business development, specifically how it will affect potential entrepreneurs our potential business creators.

In this article, we start from the perspective that COVID-19 can be a transformative opportunity for self-employed due to the new thought processes posed by the pandemic. By adopting this perspective, the well-being of the self-employed is viewed as a holistic process, rather than seeing the COVID-19 crisis as an opportunity to pay more attention to the importance of self-employment well-being.

This study has important theoretical and practical implications for the self-employed in Ecuador. At a theoretical level, understanding how the JDCS model works is an important agent for the reconstruction of the economy in order not to continue perpetuating errors in the labor model and avoid their systematization, which performs complex tasks that can decisively contribute to improving the wellbeing of self-employed persons subjected to intense labor demands. From a practical perspective, the findings of this study corroborate the idea that labor demands, labor control, and social support together affect the well-being of the self-employed, especially if the worker can promote a change in his situation through risk analysis and self-management.

Consequently, the self-employed must analyze the labor factors that affect WB.

Therefore, based on our analysis of the current environment in Ecuador and the consequences that our conclusions have for the self-employed workforce, a series of conclusions related to COVID-19 are identified. In the first place, the work environment of self-employed workers poses precarious situations and physical risks for these workers. Specifically, due to the lack of adequate regulation on occupational risk prevention by the public administration, there are situations of vulnerability for this group. The reality is 
that since there is no mandatory regulation and inspections that require the self-employed to implement this regulation, working conditions are deeply problematic and dangerous for this group. However, it is unlikely that these circumstances will change when the pandemic passes because it requires a profound reformulation of the regulations in terms of the prevention of occupational risks, and governments will prioritize economic growth. Following this idea, it is worth considering whether the time has come due to the pandemic, and due to this context of reconstruction, where governments propose labor regulations that were pending or were problematic to be carried out, such as the expansion of the labor rights of self-employed workers. In addition, the pandemic has had a great impact on the most disadvantaged communities, especially in the informal sector of the South American countries. Informal sectors in the Global South have shown great resilience to previous crises (for example, the Manabí earthquake in October 2019), and a rapid rebuilding took place. However, the nature of self-employment in the informal economy is so vulnerable that it is based mainly on family livelihoods, and it is this factor that can be key to their resilience. Wholesale structural changes are needed in society, industry, and business opportunism. The post-COVID-19 economic reconstruction can be driven by entrepreneurship or by a large growth of large companies, causing a reduction in formal and informal self-employed. Following this idea, there is already evidence that the number of self-employed has already decreased under the shadow of the pandemic.

Self-employed must explore new tools and techniques that provoke a new perception and work management, in which the risk associated with daily activities decreases through the control of these activities; this action is essential because self-employment implies direct contact with society and is key to sustainable economic growth. Any progress in this sense (for example, the creation of labor protocols through specific training) will lead to adequate labor control, which should translate into a better WB. Investing in training for the selfemployed in relation to internal risk management will improve health and stress-related aspects. In addition, the self-employed must promote a good social environment in their workplace; in addition, factors such as family and friends influence the management and decision-making of the self-employed. These strategies should reduce work stress and, as a result, increase workers' WB.

Policy decisions during the first months of the pandemic offer a premonition about how the crisis can unfold in a workplace context. In most countries, restrictions on movement and travel were tentatively relaxed from mid-April onwards (with some increase in infections). The self-employed have been allowed to open their businesses and move to be able to continue with the economic activity after justification. Depending on the countries, they have been granted aid to cover the losses caused by the suspension of the activity and the workers in their charge. Tests and regulations must be carried out in relation to all sanitary regulations. The work related to these workers is of high impact in health terms, and that is the greatest risk for the re-entry of their businesses to the post-COVID-19 world. It is unlikely that we, as a society around the world, will abandon our relationship with this figure, but on what terms are society, institutions, and organizations going to engage with self-employed workers?

This research has its limitations, and a qualitative analysis is required to know if the conditions of the work environment, public policies, education, and economic crises, among other aspects, may be affecting the dynamics of the self-employed in their working conditions, in such a way that they generate lights for the sustainability or survival of businesses. In the case of this study, a cross-sectional approach was considered, which can cause investigative biases of temporality, meaning then that it was considered only in a certain time, in which they were consulted about the working conditions of the self-employed and not precisely how sequential or phased study that, according to current conditions (pandemic), warrants an in-depth analysis of the well-being and working conditions of the self-employed in Ecuador. It is also important to indicate that the area of influence of this study was affected in 2016 by a natural phenomenon (earthquake) that caused millions in losses, which generated as emerging measures the policies of reconstruction 
and economic reactivation, among which included the creation of companies with the participation of the popular and solidarity economy. Many of the businesses observed were started from this initiative [166], which in the future could generate a longitudinal study regarding the autonomy and sustainability of business from this perspective. In general terms, understanding the complex relationship between the figure of the self-employed and well-being, being subject to deep reflections, which means potential ground for future research. Therefore, it will be relevant that it be explored carefully in such a way that the term well-being becomes operational in this field $[9,40,99]$.

Author Contributions: Conceptualization, V.N.-R. and L.Z.Z.-S..; Methodology, L.C.yL.d.R. and N.C.-V.; Software, L.C.yL.d.R. Validation, V.N.-R.; N.C.-V. and L.Z.Z.-S.; Formal Analysis, V.N.-R. and N.C.-V.; Investigation, V.N.-R.; L.C.yL.d.R.; and N.C.-V.; L.Z.Z.-S.; Resources, L.C.yL.d.R.; and N.C.-V.; Data Curation, L.C.yL.d.R. Writing-Original Draft Preparation, V.N.-R.; L.Z.Z.-S. and L.C.yL.d.R.; WritingReview \& Editing, V.N.-R. L.Z.Z.-S. and L.C.yL.d.R.; Visualization, L.C.yL.d.R.; and N.C.-V.; Supervision, N.C.-V.; Project Administration, V.N.-R. All authors have read and agreed to the published version of the manuscript.

Funding: This research received no external funding.

Acknowledgments: We thank Eurofound for providing the data set for this research. Reference [82], European Working Conditions Survey Integrated Data File, 1991-2015, [data collection], UK Data Service. SN: 7363, https:// doi.org/10.5255/UKDA-SN-7363-4.

Conflicts of Interest: The authors declare no conflict of interest.

\section{References}

1. Sharif, A.; Aloui, C.; Yarovaya, L. COVID-19 pandemic, oil prices, stock market, geopolitical risk and policy uncertainty nexus in the US economy: Fresh evidence from the wavelet-based approach. Int. Rev. Financ. Anal. 2020, 70, 101496. [CrossRef]

2. Navajas-Romero, V.; Díaz-Carrión, R.; Ariza-Montes, A. Decent Work as Determinant of Work Engagement on Dependent Self-Employed. Sustainability 2019, 11, 2512. [CrossRef]

3. World Health Organization. Coronavirus Disease (COVID-19) Outbreak (2020). Available online: https://www.who.int/ emergencies / diseases / novel-coronavirus-2019 (accessed on 3 September 2020).

4. Hall, C.M.; Scott, D.; Gössling, S. Pandemics, transformations and tourism: Be careful what you wish for. Tour. Geogr. 2020, 22, 577-598. [CrossRef]

5. Mujahid, S.; Mubarik, M.S.; Naghavi, N. Developing entrepreneurial intentions: What matters. Middle East J. Manag. 2020, 7, 41. [CrossRef]

6. Chetty, R.; Friedman, J.N.; Hendren, N.; Stephner, M. How Did COVID-19 and Stabilization Policies Affect Spending and Employment? A New Real-Time Economic Tracker Based on Private Sector Data. Natl. Bur. Econ. Res. 2020, 91, 1689-1699.

7. Shepherd, D.A. COVID 19 and Entrepreneurship: Time to Pivot? J. Manag. Stud. 2020, 57, 1750-1753. [CrossRef]

8. Abisuga-Oyekunle, O.A.; Patra, S.K.; Muchie, M. SMEs in sustainable development: Their role in poverty reduction and employment generation in sub-Saharan Africa. Afr. J. Sci. Technol. Innov. Dev. 2019, 12, 405-419. [CrossRef]

9. Gialis, S.; Tsampra, M. The diverse regional patterns of atypical employment in Greece: Production restructuring, re/deregulation and flexicurity under crisis. Geoforum 2015, 62, 175-187. [CrossRef]

10. Schulte, P.A.; Guerin, R.J.; Schill, A.L.; Bhattacharya, A.; Cunningham, T.R.; Pandalai, S.P.; Eggerth, D.; Stephenson, C.M. Considerations for Incorporating "Well-Being" in Public Policy for Workers and Workplaces. Am. J. Public Heal. 2015, 105, e31-e44. [CrossRef]

11. SENPLADES, (Secretaría Nacional de Planificación y Desarrollo. Plan Nacional de Desarrollo 2017-2021: Toda Una Vida; SENPLADES: Quito, Ecuador, 2017.

12. Nadzri, N.; Hassan, K. Development Model of Australian Employment Law: Lesson for Malaysia. Akademika 2019, 89, 53-64.

13. Diab, M.B. Towards Social Entrepreneurship and Sustainable Development in Lebanon; Lebanese International University: Bucharest, Romania, 2019; Volume 13.

14. Acs, Z.J.; Desai, S.; Klapper, L.F. What Does “Entrepreneurship” Data Really Show? Small Bus. Econ. 2008, 31, 265-281. [CrossRef]

15. Kuratko, D.F.; Morris, M.H.; Schindehutte, M. Understanding the dynamics of entrepreneurship through framework approaches. Small Bus. Econ. 2015, 45, 1-13. [CrossRef]

16. Wiklund, J.; Nikolaev, B.N.; Shir, N.; Foo, M.-D.; Bradley, S.W. Entrepreneurship and well-being: Past, present, and future. J. Bus. Ventur. 2019, 34, 579-588. [CrossRef]

17. Naudé, W.; Amorós, J.E.; Cristi, O. "Surfeiting, the appetite may sicken”: Entrepreneurship and happiness. Small Bus. Econ. 2014, 42, 523-540. [CrossRef]

18. Shir, N. Entrepreneurial Well-Being: The Payoff Structure of Business; Stockholm School of Economics: Stockholm, Finland, 2015. [CrossRef] 
19. Stephan, U. Entrepreneurs' Mental Health and Well-Being: A Review and Research Agenda. Acad. Manag. Perspect. 2018, 32, 290-322. [CrossRef]

20. Ali, M.; Rattanawiboonsom, V.; Perez, C.; Khan, A. Comparative Positioning of Small and Medium Enterprises in Bangladesh, Thailand and The Philippines. Econ. Reg. 2017, 13, 381-395. [CrossRef]

21. CEPAL. América Latina y El Caribe Ante La Pandemia Del COVID-19; CEPAL: Santiago, Chile, 2020.

22. Battista, L. Covid-19 and Self-Employment: Emergency Measures and Unsolved Challenges. Ital. Labour Law E-J. 2020, $13,85-101$.

23. Brooks, L. Scottish Hotel Sacks 12 Staff over Coronavirus Making Them Homeless. Available online: https://www.theguardian.com/ uk-news/2020/mar/20/scottish-hotel-sacks-12-staff-over-coronavirus-making-them-homeless (accessed on 13 December 2020).

24. Evans, D.; Over, M. “Society's Most Vulnerable Will Be hit as COVID-19 Cases Rise in Poorer Economies". Available online: https: / / theconversation.com/societys-most-vulnerable-will-be-hit-as-covid-19-cases-rise-in-poorer-economies-133814 (accessed on 11 December 2020).

25. ECLAC, U.N. Covid-19 Observatory in Latin America and the Caribbean Economic and Social Impact. Available online: https:/ / www.cepal.org/en/topics/covid-19 (accessed on 13 December 2020).

26. Hernandez-Sanchez, B.; Cardella, G.M.; Sanchez, J. Psychological Factors that Lessen the Impact of COVID-19 on the SelfEmployment Intention of Business Administration and Economics' Students from Latin America. Int. J. Environ. Res. Public Health 2020, 17, 5293. [CrossRef] [PubMed]

27. Martín-Mayoral, F. Estado y Mercado En La Historia de Ecuador. Nueva Soc. 2009, 221, 120-136.

28. Quintana, L.; Salas, C.; Correa, R. Crisis, Employment and Inequality in Latin America: A National and Regional Analysis between Mexico, Brazil and Ecuador. J. Reg. Res. 2019, 43, 129-147.

29. Lasio, V.; Ordeñana, X.; Caicedo, G.; Samaniego, A.; Izquierdo, E. Global Entrepeneurship Monitor; ESPAE-ESPOL: Quito, Ecuador, 2017.

30. Johnson, J.V.; Hall, E.M. Job strain, work place social support, and cardiovascular disease: A cross-sectional study of a random sample of the Swedish working population. Am. J. Public Health 1988, 78, 1336-1342. [CrossRef] [PubMed]

31. Karasek, R.A. Job Demands, Job Decision Latitude, and Mental Strain: Implications for Job Redesign. Adm. Sci. Q. 1979, 24, 285-308. [CrossRef]

32. Nielsen, M.B.; Einarsen, S.V. What we know, what we do not know, and what we should and could have known about workplace bullying: An overview of the literature and agenda for future research. Aggress. Violent Behav. 2018, 42, 71-83. [CrossRef]

33. Salin, D. Personality and Social Psychology Risk Factors of Workplace Bullying for Men and Women: The Role of the Psychosocial and Physical Work Environment. Scand. J. Psychol. 2015, 56, 69-77. [CrossRef]

34. Ariza-Montes, A.; Arjona-Fuentes, J.M.; Han, H.; Law, R. Work environment and well-being of different occupational groups in hospitality: Job Demand-Control-Support model. Int. J. Hosp. Manag. 2018, 73, 1-11. [CrossRef]

35. Asif, F.; Javed, U.; Janjua, S.Y. The Job Demand-Control-Support Model and Employee Wellbeing: A Meta-Analysis of Previous Research. Pak. J. Psychol. Res. 2018, 33, 203-221.

36. Chambel, M.J.; Carvalho, V.S.; Cesário, F.; Lopes, S. The work-to-life conflict mediation between job characteristics and well-being at work. Career Dev. Int. 2017, 22, 142-164. [CrossRef]

37. Ibrahim, R.Z.A.R.; Saputra, J.; Bakar, A.A.; Dagang, M.M.; Nazilah, S. Role of Supply Chain Management on the Job Control and Social Support for Relationship between Work-Family Conflict and Job Satisfaction. Int. J. Supply Chain Manag. 2019, 8, $907-913$.

38. Mivšek, P.; Aimala, A.-M.; Žvanut, B.; Tuomi, J.; Bostjan, Z.; Jouni, T. Midwifery students' well-being among undegraduates in Slovenia: A pilot study. Midwifery 2018, 61, 63-65. [CrossRef] [PubMed]

39. Schilling, R.; Colledge, F.; Ludyga, S.; Pühse, U.; Brand, S.; Gerber, M. Does Cardiorespiratory Fitness Moderate the Association between Occupational Stress, Cardiovascular Risk, and Mental Health in Police Officers? Int. J. Environ. Res. Public Health 2019, 16, 2349. [CrossRef]

40. Karasek, R.; Theorell, T. Healthy Work: Stress, Productivity, and the Reconstruction of Working Life; Basic Book: New York, NY, USA, 1990.

41. Bencsik, P.; Chuluun, T. Comparative well-being of the self-employed and paid employees in the USA. Small Bus. Econ. 2019. [CrossRef]

42. Ferrer-I-Carbonell, A. Income and well-being: An empirical analysis of the comparison income effect. J. Public Econ. 2005, 89, 997-1019. [CrossRef]

43. McBride, M. Relative-income effects on subjective well-being in the cross-section. J. Econ. Behav. Organ. 2001, 45, 251-278. [CrossRef]

44. Clark, A.E.; Frijters, P.; Shields, M.A. Relative Income, Happiness, and Utility: An Explanation for the Easterlin Paradox and Other Puzzles. J. Econ. Lit. 2008, 46, 95-144. [CrossRef]

45. Easterlin, R.A. Income and Happiness: Towards a Unified Theory. Econ. J. 2001, 111, 465-484. [CrossRef]

46. Stutzer, A. The Role of Income Aspirations in Individual Happiness. J. Econ. Behav. Organ. 2004, 54, 89-109. [CrossRef]

47. Tideman, S.G. Gross National Happiness. In Ethical Principles and Economic Transformation; Zsolani, L., Ed.; Springer: New York, NY, USA, 2011; pp. 133-153. [CrossRef]

48. Benz, M.; Frey, B.S. Being Independent is a Great Thing: Subjective Evaluations of Self-Employment and Hierarchy. Economica 2008, 75, 362-383. [CrossRef] 
49. Carter, N.M.; Gartner, W.B.; Shaver, K.G.; Gatewood, E.J. The career reasons of nascent entrepreneurs. J. Bus. Ventur. 2003, 18, 13-39. [CrossRef]

50. Gimeno, J.; Folta, T.B.; Cooper, A.C.; Woo, C.Y. Survival of the Fittest? Human Entrepreneurial Capital and the Persistence of Firms Underperforming. Adm. Sci. Q. 1997, 42, 750-783. [CrossRef]

51. López-Araújo, B.; Osca Segovia, A. El papel del modelo Demandas-Control-Apoyo en la salud de trabajadores de la construcción. Psicothema 2011, 23, 119-125.

52. Blanchflower, D.G.; Oswald, A.J. Money, Sex and Happiness: An Empirical Study. Scand. J. Econ. 2004, 106, 393-415. [CrossRef]

53. Blanchflower, D.G.; Oswald, A.J. What Makes an Entrepreneur? J. Labor Econ. 1998, 16, 26-60. [CrossRef]

54. Rodríguez-Pose, A. The revenge of the places that don't matter (and what to do about it). Camb. J. Reg. Econ. Soc. 2018, 11, 189-209. [CrossRef]

55. Moretti, E. The New Geography of Jobs; Houghton Mifflin Harcout, Ed.; Houghton Mifflin Harcout: Boston, MA, USA; New York, NY, USA, 2012.

56. Campaña, J.C.; Giménez-Nadal, J.I.; Molina, J.A. Self-employed and Employed Mothers in Latin American Families: Are There Differences in Paid Work, Unpaid Work, and Child Care? J. Fam. Econ. Issues 2020, 41, 52-69. [CrossRef]

57. Canelas, C. Informality and poverty in Ecuador. Small Bus. Econ. 2019, 53, 1097-1115. [CrossRef]

58. Canelas, C. Minimum Wage and Informality in Ecuador; 6 B, 00160; WIDER Working Paper: Helsinki, Finland, 2014.

59. Jara, H.X.; Rodríguez, D. Financial Disincentives to Formal Work: Evidence from Ecuador and Colombia; No. 2019/14; WIDER Working Paper: Helsinki, Finland, 2019.

60. Binder, M.; Freytag, A. Volunteering, subjective well-being and public policy. J. Econ. Psychol. 2013, 34, 97-119. [CrossRef]

61. Binder, M.; Coad, A. How Satisfied Are the Self-Employed? A Life Domain View. J. Happiness Stud. 2015, 17, 1409-1433. [CrossRef]

62. Binder, M.; Coad, A.J.-L. Life satisfaction and self-employment: A matching approach. Small Bus. Econ. 2013, 40, 1009-1033. [CrossRef]

63. Hessels, J.; Rietveld, C.A.; Van Der Zwan, P. Self-employment and work-related stress: The mediating role of job control and job demand. J. Bus. Ventur. 2017, 32, 178-196. [CrossRef]

64. Shir, N.; Nikolaev, B.N.; Wincent, J. Entrepreneurship and well-being: The role of psychological autonomy, competence, and relatedness. J. Bus. Ventur. 2019, 34, 105875. [CrossRef]

65. Schmidt, B.; Schneider, M.; Seeger, P.; Van Vianen, A.; Loerbroks, A.; Herr, R.M. A Comparison of Job Stress Models Associations with Employee Well-Being, Absenteeism, Presenteeism, and Resulting Costs. J. Occup. Environ. Med. 2019, 61, 535-544. [CrossRef] [PubMed]

66. Ravallion, M. Income inequality in the developing world. Science 2014, 344, 851-855. [CrossRef]

67. Merino-Salazar, P.; Artazcoz, L.; Cornelio, C.; Iñiguez, M.J.I.; Rojas, M.; Martínez-Iñigo, D.; Vives, A.; Funcasta, L.; Benavides, F.G. Work and health in Latin America: Results from the working conditions surveys of Colombia, Argentina, Chile, Central America and Uruguay. Occup. Environ. Med. 2017, 74, 432-439. [CrossRef]

68. García, A.R.G.; Portalanza-Chavarría, C.A.; Arias-Ulloa, C.A.; Espinoza-Samaniego, C.E. Salaried Workers' Self-Perceived Health and Psychosocial Risk in Guayaquil, Ecuador. Int. J. Environ. Res. Public Health 2020, 17, 9099. [CrossRef] [PubMed]

69. Nikolaev, B.; Boudreaux, C.J.; Wood, M. Entrepreneurship and Subjective Well-Being: The Mediating Role of Psychological Functioning. Entrep. Theory Pract. 2019, 44, 557-586. [CrossRef]

70. Bjørnskov, C.; Foss, N.J. Well-being and entrepreneurship: Using establishment size to identify treatment effects and transmission mechanisms. PLoS ONE 2020, 15, e0226008. [CrossRef] [PubMed]

71. Möhring, K.; Naumann, E.; Reifenscheid, M.; Wenz, A.; Rettig, T.; Krieger, U.; Friedel, S.; Finkel, M.; Cornesse, C.; Blom, A.G. The COVID-19 Pandemic and Subjective Well-Being: Longitudinal Evidence on Satisfaction with Work and Family. Eur. Soc. 2020, 1-17. [CrossRef]

72. Pagán-Castaño, E.; Maseda-Moreno, A.; Santos-Rojo, C. Wellbeing in work environments. J. Bus. Res. 2020, 115, 469-474 [CrossRef]

73. Ibrahim, R.Z.A.R.; Ohtsuka, K.; Demand-control-, J. Review of the Job Demand-Control and Job Demand-Control-Support Models: Elusive Moderating Predictor Effects and Cultural Implications Model. Southeast Asia Psychol. J. 2012, 1, 10-21.

74. Jonsdottir, I.J.; Rafnsdottir, G.L.; Ólafsdóttir, T. Job strain, gender and well-being at work: A case study of public sector line managers. Int. J. Work. Health Manag. 2020, 13, 445-460. [CrossRef]

75. Johnson, J.V.; Hall, E.M.; Theorell, T. Combined effects of job strain and social isolation on cardiovascular disease morbidity and mortality in a random sample of the Swedish male working population. Scand. J. Work. Environ. Health 1989, 15, 271-279. [CrossRef]

76. Cortés, A.; García, T.M.; Moro-Egido, A.I. Heterogeneous Self-Employment and Satisfaction in Latin America. J. Econ. Psychol. 2013, 39, 44-61.

77. González Sánchez, V.M. Self-Employment, Knowledge and Economic Growth: An Empirical Study for Latin American Countries. Contemp. Econ. 2018, 12, 473-484. [CrossRef]

78. Brough, P. Comparing the Influence of Traumatic and Organizational Stressors on the Psychological Health of Police, Fire, and Ambulance Officers. Int. J. Stress Manag. 2004, 11, 227-244. [CrossRef]

79. Day, A.L.; Livingstone, H.A. Chronic and acute stressors among military personnel: Do coping styles buffer their negative impact on health? J. Occup. Health Psychol. 2001, 6, 348-360. [CrossRef] [PubMed] 
80. Li, M. Self-Employed and Work-Related Welbeing. A Comparative Study between Self-Employed and Organizational Employees on Burnout and Engagement Using Job Demand-Control-Support Model; Utrecht University: Utrecht, The Netherlands, 2019.

81. Andersson, P. Happiness and health: Well-being among the self-employed. J. Socio-Econ. 2008, 37, 213-236. [CrossRef]

82. Stephan, U.; Roesler, U. Health of Entrepreneurs vs. Employees in a National Representative Sample. J. Occup. Organ. Psychol. 2010, 83, 717-738. [CrossRef]

83. Fagan, H.; Neill, S.; Wooldridge, B.R. Exploring the Intention to Use Computers: An Empirical Investigation of the Role of Intrinsic Motivation, Extrinsic Motivation, and Perceived Ease of Use. J. Comput. Inf. Syst. 2008, 48, 31-37.

84. Siemsen, E.; Balasubramanian, S.; Roth, A.V. Incentives That Induce Task-Related Effort, Helping, and Knowledge Sharing in Workgroups. Manag. Sci. 2007, 53, 1533-1550. [CrossRef]

85. Pratt, P.E.; Kwon, J.; Rew, M.L. Perceived Job Importance and Job Performance Satisfaction of Selected Clinical Nutrition Management Responsibilities. J. Am. Diet. Assoc. 2005, 105, 1128-1133. [CrossRef]

86. Lu, H.; Barriball, K.L.; Zhang, X.; While, A.E. Job satisfaction among hospital nurses revisited: A systematic review. Int. J. Nurs. Stud. 2012, 49, 1017-1038. [CrossRef] [PubMed]

87. Edelson, D.C.; Joseph, D.M. The Interest-Driven Learning Design Framework: Motivating Learning through Usefulness. In Proceedings of the 6th International Conference on Learning Sciences; International Society of the Learning Sciences: Santa Mónica, CA, USA, June 2004; pp. 166-173.

88. Navajas-Romero, V.; Del Rio, L.C.Y.L.; Ceular-Villamandos, N. Analysis of Wellbeing in Nongovernmental Organizations' Workplace in a Developed Area Context. Int. J. Environ. Res. Public Health 2020, 17, 5818. [CrossRef]

89. Fritsch, M.; Sorgner, A.; Zoellner, M. Self-employment and well-being across institutional contexts. J. Bus. Ventur. 2020, $34,105946$. [CrossRef]

90. Abreu, M.; Oner, O.; Brouwer, A.; Van Leeuwen, E. Well-being effects of self-employment: A spatial inquiry. J. Bus. Ventur. 2019, 34, 589-607. [CrossRef]

91. Ryff, C.D. Entrepreneurship and eudaimonic well-being: Five venues for new science. J. Bus. Ventur. 2018, 34, 646-663. [CrossRef] [PubMed]

92. Baron, R.A.; Franklin, R.J.; Hmieleski, K.M. Why Entrepreneurs Often Experience Low, Not High, Levels of Stress. J. Manag. 2016, 42, 742-768. [CrossRef]

93. Hahn, V.C.; Frese, M.; Binnewies, C.; Schmitt, A. Happy and Proactive? The Role of Hedonic and Eudaimonic Well-Being in Business Owners' Personal Initiative. Entrep. Theory Pract. 2012, 36, 97-114. [CrossRef]

94. Hamilton, B.H. Does Entrepreneurship Pay? An Empirical Analysis of the Returns to Self-Employment. J. Political-Econ. 2000, 108, 604-631. [CrossRef]

95. Román, C.; Congregado, E.; Millán, J.M. Dependent self-employment as a way to evade employment protection legislation. Small Bus. Econ. 2009, 37, 363-392. [CrossRef]

96. Millán, A.; Millán, J.M.; Caçador-Rodrigues, L. Disclosing 'masked employees' in Europe: Job control, job demands and job outcomes of 'dependent self-employed workers'. Small Bus. Econ. 2020, 55, 461-474. [CrossRef]

97. Gunnarsson, K.; Vinga, E. Self-rated health and working conditions of small-scale enterprisers in Sweden. Ind. Health 2007, 45, 775-780. [CrossRef] [PubMed]

98. Hagqvist, E.; Toivanen, S.; Vinberg, S. Time strain among employed and self-employed women and men in Sweden. Soc. Health Vulnerability 2015, 6, 29183. [CrossRef]

99. Hagqvist, E.; Toivanen, S.; Vinberg, S. The gender time gap: Time use among self-employed women and men compared to paid employees in Sweden. Time Soc. 2019, 28, 680-696. [CrossRef]

100. Nordenmark, M.; Vinberg, S.; Strandh, M. Job control and demands, work-life balance and wellbeing among self-employed men and women in Europe. Vulnerable Groups Incl. 2012, 3, 18896. [CrossRef]

101. Gorgievski, M.J.; Bakker, A.B.; Schaufeli, W.B.; Van Der Veen, H.B.; Giesen, C.W.M. Financial problems and psychological distress: Investigating reciprocal effects among business owners. J. Occup. Organ. Psychol. 2010, 83, 513-530. [CrossRef]

102. Wincent, J.; Örtqvist, D.; Drnovsek, M. The entrepreneur's role stressors and proclivity for a venture withdrawal. Scand. J. Manag. 2008, 24, 232-246. [CrossRef]

103. Wolfe, M.T.; Patel, P.C. Labor of love? The influence of work-conditions among self-employed and work stress. J. Bus. Ventur. Insights 2019, 11, e00118. [CrossRef]

104. Miraglia, M.; Johns, G. Going to work ill: A meta-analysis of the correlates of presenteeism and a dual-path model. J. Occup. Heal. Psychol. 2016, 21, 261-283. [CrossRef]

105. Athota, S.; Budhwar, P.; Malik, A. Influence of Personality Traits and Moral Values on Employee Well-Being, Resilience and Performance: A Cross-National Study. Appl. Psychol. 2020, 69, 653-685. [CrossRef]

106. Maher, K.; Randall, R.; Bateman, N.; Travers, C. Changes in work conditions, work-related wellbeing and operational effectiveness: Alternative crewing in one uk fire and rescue service. In Proceedings of the Division of Occupational Psychology Annual Conference 2019, Chester, UK, 9-11 January 2019.

107. Fioramonti, L.; Coscieme, L.; Mortensen, L.F. From gross domestic product to wellbeing: How alternative indicators can help connect the new economy with the Sustainable Development Goals. Anthr. Rev. 2019, 6, 207-222. [CrossRef]

108. Finstad, G.L.; Ariza-Montes, A.; Giorgi, G.; Lecca, L.I.; Arcangeli, G.; Mucci, N. The JDCS model and blue-collar bullying: Decent working conditions for a healthy environment. Int. J. Environ. Res. Public Health 2019, 16, 3411. [CrossRef] [PubMed] 
109. Camacho, F.R.; Bajaña, Y.S. Impact of Foreign Direct Investment on Economic Growth: Comparative Analysis in Ecuador, Peru And Colombia 1996-2016. Int. J. Econ. Financ. Issues 2020, 10, 247-257. [CrossRef]

110. INEC. Fascículo Provincial Manabí, Resultados de Censo 2010; Administración Central: Quito, Ecuador, 2010.

111. INEC (Instituto Nacional de Estadísticas y Censos). Indicadores de Mercado Laboral 2018; WIDER Working Paper: Quito, Ecuador, 2018.

112. Villarreal, A. We're scared': US Service Workers See Livelihoods Vanish Amid Coronavirus. Available online: https://www. theguardian.com/world/2020/mar/17/service-workers-coronavirus-us-wages-tips-restaurants-bars (accessed on 9 December 2020).

113. Shivakumar, B.L.; Rangaraj, T. Mental wellbeing status of online and work from home women employees with special reference to Coimbatore, Tamilnadu. Mukt Shabd J. 2020, 9, 1971-1987.

114. Park, J.; Oh, Y.S.; Kim, Y. Psychological well-being of South Korean employees in different occupational classes. Arch. Environ. Occup. Health 2020, 1-13. [CrossRef] [PubMed]

115. Marin-Garcia, J.A.; Tomas, B.M.; Losilla, J.-M. Changes in the Association between European Workers' Employment Conditions and Employee Well-Being in 2005, 2010 and 2015. Int. J. Environ. Res. Public Health 2020, 17, 1048. [CrossRef] [PubMed]

116. INEC. Encuesta Nacional de Empleo, Desempleo y Subempleo; Administración Central: Quito, Ecuador, 2018.

117. Erdogan, B.; Bauer, T.N.; Truxillo, D.M.; Mansfield, L.R. Whistle While You Work. J. Manag. 2012, 38, 1038-1083. [CrossRef]

118. Cramer, J.S. Logit Models from Economics and Other Fields; Cambridge University Press (CUP): Cambridge, UK, 2003.

119. Greene, W.H. The Econometric Approach to Efficiency Analysis. In The Measurement of Productive Efficiency: Techniques and Applications; Fried, H., Schmidt, S., Eds.; Oxford Scholarship Online: Oxford, UK, 1993; pp. 68-119.

120. Washington, S.P.; Karlaftis, M.G.; Mannering, F.L. Statistical and Econometric Methods for Transportation Data Analysis, 2nd ed.; Chapman and Hall/CRC: Boca Raton, FL, USA, 2011.

121. Carree, M.A.; Thurik, R. The Impact of Entrepreneurship on Economic Growth. In Handbook of Entrepreneurship Research; Springer: New York, NY, USA, 2010; pp. 557-594.

122. Koellinger, P.D.; Thurik, A.R. Entrepreneurship and the Business Cycle. Rev. Econ. Stat. 2012, 94, 1143-1156. [CrossRef]

123. Audretsch, D.B.; Keilbach, M. Entrepreneurship and regional growth: An evolutionary interpretation. J. Evol. Econ. 2004, 14, 605-616. [CrossRef]

124. Caliendo, M.; Künn, S. Start-up subsidies for the unemployed: Long-term evidence and effect heterogeneity. J. Public Econ. 2011, 95, 311-331. [CrossRef]

125. Lu, L.; Kao, S.; Cooper, C.L.; Spector, P.E. Managerial Stress, Locus of Control, and Job Strain in Taiwan and UK: A Comparative Study. Int. J. Stress Manag. 2000, 7, 209-226. [CrossRef]

126. Wennekers, S.; Thurik, A. Linking Entrepreneurship and Economic Growth. Small Bus. Econ. 1999, 13, 27-56. [CrossRef]

127. Robles-Zambrano, G.; Moreno-Arvelo, P.; Triviño-Vera, K. El Subempleo: Fenómeno Que Atenta Contra La Estabilidad Laboral En Ecuador. Rev. Dilemas Contemp. Educ. Politica Valores 2019, 6, 1-10.

128. Hessels, J.; Rietveld, C.A.; Thurik, R.; Van Der Zwan, P. Depression and Entrepreneurial Exit. Acad. Manag. Perspect. 2018, 32, 323-339. [CrossRef]

129. Gasparini, L.; Tornarolli, L. Labor Informality in Latin America and the Caribbean: Patterns and Trends from Household Survey Microdata; Desarrollo y Sociedad: Bogotá, Columbia, 2009; pp. 13-80. [CrossRef]

130. Tokman, V. Informality in Latin America: Interpretations, Facts and Opportunities; Working paper 2009-1; Economic Commission for Latin America and the Caribbean (ECLAC)—Trade and, Industrial Policy Strategies (TIPS): Pretoria, South Africa, 2009.

131. Quinn, J.F. Labor-force participation patterns of older self-employed workers. Soc. Secur. Bull. 1980, 43, 17-28.

132. Parker, S.C. The Economics of Self-Employment and Entrepreneurship; Cambridge University Press (CUP): Cambridge, UK, 2004.

133. Jamal, M. Self-Employment and Quality of Work and Nonwork Life: A Study in Cross-Cultural Management. J. Small Bus. Entrep. 2009, 22, 455-466. [CrossRef]

134. Cardon, M.S.; Patel, P.C. Is Stress Worth it? Stress-Related Health and Wealth Trade-Offs for Entrepreneurs. Appl. Psychol. 2015, 64, 379-420. [CrossRef]

135. Jorm, A.F.; Christensen, H.; Rodgers, B.; Strazdins, L.; D'Souza, R.M. The associations between work stress and mental health: A comparison of organizationally employed and self-employed workers. Work Stress 2004, 18, 231-244. [CrossRef]

136. Torrès, O.; Thurik, R. Small business owners and health. Small Bus. Econ. 2019, 53, 311-321. [CrossRef]

137. Graham, C.; Felton, A. Does Inequality Matter to Individual Welfare? An Initial Exploration Based on Happiness Surveys from Latin America; CSED Seminar Series; CSED Working Paper no. 38; Revista Desarrollo y Sociedad P: Washington, DC, USA, 2005.

138. Graham, C.; Felton, A. Inequality and happiness: Insights from Latin America. J. Econ. Inequal. 2006, 4, 107-122. [CrossRef]

139. Graham, C.; Pettinato, S. Happiness, Markets, and Democracy: Latin America in Comparative Perspective. J. Happiness Stud. 2001, 2, 237-268. [CrossRef]

140. Lora, E. Beyond Facts: Understanding Quality of Life. Development in the Americas; Inter-American Development Bank: London, UK, 2008.

141. Boyd, D.P.; Gumpert, D.E. Coping with Entrepreneurial Stress. Harv. Bus. Rev. 1983, 61, 44.

142. Eden, D. Organizational membership vs self-employment: Another blow to the American dream. Organ. Behav. Hum. Perform. 1975, 13, 79-94. [CrossRef]

143. Harris, J.A.; Saltstone, R.; Fraboni, M. An Evaluation of the Job Stress Questionnaire with a Sample of Entrepreneurs. J. Bus. Psychol. 1999, 13, 447-455. [CrossRef]

144. World Health Organization. World Health Statistics: Monitoring Health for the SDGs, Sustainable Development Goals; World Health Organization: Geneva, Switzerland, 2018. 
145. Millán, J.J.; Hessels, J.; Thurik, R.; Aguado, R. Determinants of job satisfaction: A European comparison of self-employed and paid employees. Small Bus. Econ. 2013, 40, 651-670. [CrossRef]

146. Araque, W.; Argüello, A.; Rivera, J. AEI Index. 2019. Available online: https://www.uasb.edu.ec/documents/62057/3015515/ AEI+Index+2019/01592d21-eba8-484b-bca5-7773a5d14615 (accessed on 15 January 2021).

147. Araque, W.; Argüello, A. Panorama Actual y Perspectivas Futuras sobre los Efectos del Covid-19 en el Empleo y la Economía del Ecuador. Available online: https: / / www.uasb.edu.ec/documents / 62057/0/Panorama+y+perspectivas+covid-19/fb7a087e-89 36-439c-934f-eccc811c455a (accessed on 15 January 2021).

148. Nguyen, H.; Sawang, S. Juggling or Struggling? Work and Family Interface and Its Buffers among Small Business Owners. Entrep. Res. J. 2016, 6, 207-246. [CrossRef]

149. Buttner, E.H. Entrepreneurial Stress: Is it hazardous to your health? J. Manag. Issues 1992, 4, 223-240.

150. Prottas, D.J.; Thompson, C.A. Stress, satisfaction, and the work-family interface: A comparison of self-employed business owners, independents, and organizational employees. J. Occup. Heal. Psychol. 2006, 11, 366-378. [CrossRef]

151. Fasone, V.; Puglisi, M. Entrepreneur and Risk: A Systematic Literature Review with a Focus on Small Business. Piccola Impresa Small Bus. 2019. [CrossRef]

152. Sehnbruch, K.; González, P.; Apablaza, M.; Méndez, R.; Arriagada, V. The Quality of Employment (QoE) in nine Latin American countries: A multidimensional perspective. World Dev. 2020, 127, 104738. [CrossRef]

153. Salas, M.L.; Quezada, S.; Basagoitia, A.; Fernández, T.; Herrera, R.; Parra, M.; Muñoz, D.M.; Weigl, M.; Radon, K. Working Conditions, Workplace Violence, and Psychological Distress in Andean Miners: A Cross-sectional Study Across Three Countries. Ann. Glob. Health 2015, 81, 465-474. [CrossRef]

154. Greco, P.B.T.; Magnago, T.S.B.D.S.; Lopes, L.F.D.; Prochnow, A.; Tavares, J.P.; Viero, N.C. Psychosocial stress and minor psychiatric disorders among Agentes Socioeducadores. Rev. Lat.-Am. Enferm. 2012, 20, 971-979. [CrossRef]

155. Rauch, A.; Fink, M.; Hatak, I. Stress Processes: An Essential Ingredient in the Entrepreneurial Process. Acad. Manag. Perspect. 2018, 32, 340-357. [CrossRef]

156. Semerci, A.B. The Effect of Social Support on Job Stress of Entrepreneurs. Acad. Entrep. J. 2016, $22,41$.

157. Nambisan, S.; Wright, M.; Feldman, M.P. The digital transformation of innovation and entrepreneurship: Progress, challenges and key themes. Res. Policy 2019, 48, 103773. [CrossRef]

158. Baron, R.A.; Mueller, B.A.; Wolfe, M.T. Self-efficacy and entrepreneurs' adoption of unattainable goals: The restraining effects of self-control. J. Bus. Ventur. 2016, 31, 55-71. [CrossRef]

159. Mette, J.; Wirth, T.; Nienhaus, A.; Harth, V.; Mache, S. "I need to take care of myself": A qualitative study on coping strategies, support and health promotion for social workers serving refugees and homeless individuals. J. Occup. Med. Toxicol. 2020, 15, 19. [CrossRef]

160. Brüderl, J.; Preisendörfer, P. Network Support and the Success of Newly Founded Business. Small Bus. Econ. 1998, 10, 213-225. [CrossRef]

161. Arregle, J.-L.; Batjargal, B.; Hitt, M.A.; Webb, J.W.; Miller, T.; Tsui, A.S. Family Ties in Entrepreneurs' Social Networks and New Venture Growth. Entrep. Theory Pract. 2013, 39, 313-344. [CrossRef]

162. Caines, V.; Earl, J.K.; Bordia, P. Self-Employment in Later Life: How Future Time Perspective and Social Support Influence Self-Employment Interest. Front. Psychol. 2019, 10, 448. [CrossRef]

163. Casey, B.H. The Employment of Older People: Can We Learn from Japan? Geneva Pap. Risk Insur.-Issues Pract. 2005, 30, 620-637. [CrossRef]

164. Mendoza, C.A.; Jara, B. Natural Disasters and Informality: Are local labor markets impacted after an earthquake? Reg. Sci. Policy Pract. 2020, 12, 125-157. [CrossRef]

165. Doern, R.; Williams, N.; Vorley, T. Special issue on entrepreneurship and crises: Business as usual? An introduction and review of the literature. Entrep. Reg. Dev. 2019, 31, 400-412. [CrossRef]

166. Cobeña-Andrade, X.; Recalde-Rodríguez, J. Agenda de Reactivación Económica y Productiva de las Zonas Afectadas por el Terremoto del 16 de Abril de 2016; Secretaria Técnica del Comité de Reconstrución y Reactivación Productiva: Portoviejo, Ecuador, 2016. 